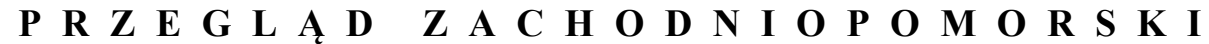 ROCZNIK XXXV (LXIV) ROK 2020 ZESZYT 2
}

\section{$\begin{array}{lllllllll}\mathbf{A} & \mathbf{R} & \mathbf{T} & \mathbf{Y} & \mathbf{K} & \mathbf{U} & \mathbf{L} & \mathbf{Y}\end{array}$}

\author{
Ewa GWIAZDOWSKA \\ https://orcid.org/0000-0002-0174-5771 \\ Muzeum Narodowe w Szczecinie \\ e.gwiazdowska@muzeum.szczecin.pl
}

\section{Klejnot Kraju*. Od Pedagogium do Gimnazjum FUNDACJI MARIACKIEJ - IKONOGRAFIA}

Słowa kluczowe: Szczecin, Gimnazjum Mariackie w Szczecinie, Fundacja Mariacka, Domy Profesorskie

Keywords: incunables, old prints, Marian Gymnasium in Szczecin, fragments, binding wastepaper

Najznaczniejsza i najstarsza szczecińska placówka szkolna posiada stosownie do swej rangi ikonografię najobszerniejszą i obejmującą najrozleglejszy zakres czasowy. Odzwierciedla się w niej znaczenie, jakie nadali szkole jej założyciele i fundatorzy - pomorscy Gryfici, a potem następni władcy Pomorza i władze administracyjne zarządzające krajem. Ikonografia obejmuje całość pierwotnego założenia, czyli budynki, w których odbywało się nauczanie, budynki pomocnicze i gospodarcze oraz te, w których znajdowały się mieszkania rektora, nauczycieli oraz pracowników obsługi szkoły, informuje o przebudowach oraz o kolejnych, nowych siedzibach szkoły. Źródła obrazowe przedstawiające szkołę powstawały w okresie od czwartej ćwierci XVI wieku po pierwszą połowę XX wieku. Są to głównie grafiki i rysunki oraz wtórne wobec nich wyroby ceramiczne. Część ikonografii to także fotografie.

* Gryfici w korespondencji dotyczącej Pedagogium określali je jako „Kleinod des Landes”, Harald Scherbarth, „Zur Stiftung St. Marien und ihrer Schulen”, Stettiner Bürgerbrief (1993): 72. 
Przedstawienie szkoły rozpoznawalne jest już na najstarszym znanym widoku Szczecina, miedziorycie Stettin wykonanym przez Fransa Hogenberga (1535 Mechelen - 1590 Kolonia?) według pierwowzoru sporządzonego przez nieznanego rysownika i opublikowanym w czwartym tomie dzieła Georga Brauna i Fransa Hogenberga, Civitates orbis terrarum, Coloniae Agrippinae 1588. Na 41. karcie publikacji, której tytuł w wolnym tłumaczeniu znaczy „Miasta świata”, umieszczono rodzaj planu miasta - widok od strony zachodniej z lotu ptaka ${ }^{1}$. Na planie widoczny jest, przylegający do kościoła Mariackiego od północnej strony, wąski pas zabudowy z arkadowym portalem znajdującym się obok węgła kościoła. Za tą zabudową - równolegle do niej - po lewej stronie wznosi się wysoki, podłużny budynek. Po północnej stronie dziedzińca przykościelnego stoi rzędem kilka budynków różnej wielkości. Harald Scherbarth, relacjonując archiwalne dokumenty z czasów książęcych donosi, że szkoła katedralna przy kościele Mariackim wymieniana była w aktach od 1266 roku. W późniejszym okresie mieściła się przy Kleine Domstrasse (obecnej ul. Mariackiej) w siedzibie kapituły znajdującej się między kościołem i domami kanoników². Porównanie tych danych z ikonografią prowadzi do wniosku, że widok szkoły przedstawiony na rycinie Hogenberga z 1588 roku w sensie ogólnym odpowiada usytuowaniu i sytuacji lokalowej szkoły w średniowieczu. Duży budynek, to zapewne kapitularz, a domy położone wzdłuż północnego odcinka murów miejskich są mieszkaniami kanoników. Natomiast wąski pas zabudowy od strony ul. Mariackiej byłby zachodnim skrzydłem krużganka. Zatem pierwszy widok Szczecina pozwala mniej więcej poznać jak wyglądała w średniowieczu, kiedy pełniła rolę szkoły katedralnej. Jednak w świetle badań zachowanych akt przeprowadzonych przez Carla Fredricha, omawiany widok jest mocno uproszczony ${ }^{3}$. Fredrich pisze bowiem, że kapitularz stał na zachód od krużganka, a od północy sąsiadował z nim budynek szkoły katedralnej i przypuszczalnie jedna z kurii, czyli domów mieszkalnych kanoników. Te dwie, względnie trzy budowle zajmowały pierzeję ul. Mariackiej aż do jej rogu. Na rycinie Hogenberga z 1588 roku brak w ogóle

\footnotetext{
1 Miedzioryt, papier żeberkowy, 325 x 494 mm, Muzeum Narodowe w Szczecinie (dalej: MNS), $\mathrm{nr}$ inw. MNS/Graf/2631; reprodukcja w: Ewa Gwiazdowska, Widoki Szczecina. Źródta ikonograficzne do dziejów miasta od XVI wieku do 1945 roku. Ansichten von Stettin. Ikonographische Quellen zur Stadtgeschichte vom 16. Jahrhundert bis zum Jahr 1945 (Szczecin: Muzeum Narodowe w Szczecinie, 2001): 77-78, il. 8.

2 Scherbarth, ,Zur Stiftung”, 73.

3 Carl Fredrich, „Die ehemalige Marienkirche zu Stettin und ihr Besitz. II”, Baltische Studien. Neue Folge 23 (1920): 27.
} 
śladów pozostałych skrzydeł krużganków, czyli północnego, wschodniego i południowego.

Gryfici przywiązywali duże znaczenie do szkoły, gdyż funkcjonowała przy świątyni, która była kościołem domowym władców Pomorza i miejscem ich pochówku. W okresie renesansu, kiedy szkolnictwo stało się jednym z wyznaczników prestiżu dworu uznali, że miasto rezydencjonalne powinno posiadać stosowną do tego uczelnię i przekształcili szkołę katedralną, w 1543 roku, w Pedagogium nadając mu status szkoły półwyższej. Ten fakt znalazł odzwierciedlenie w zaktualizowanym planie Szczecina Fransa Hogenberga.

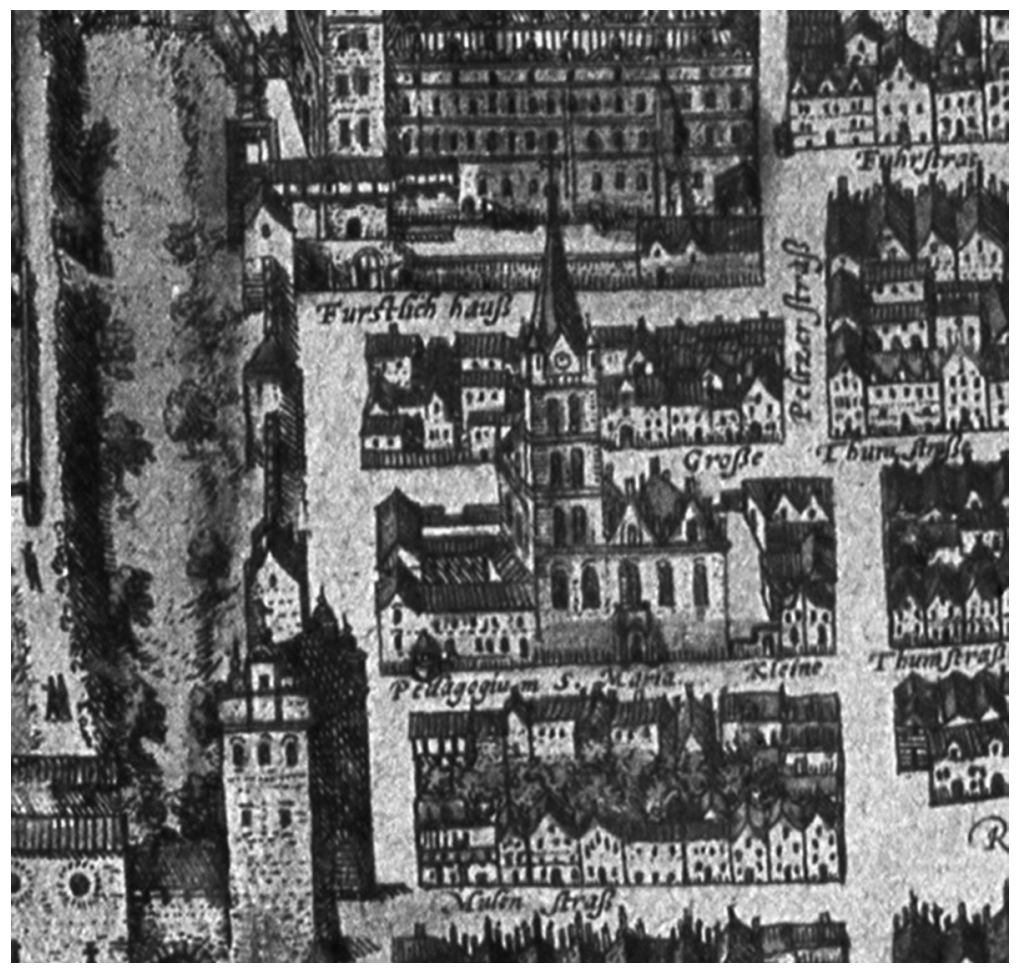

Rycina 1. Frans Hogenberg, Widok Pedagogium, fragment kompozycji Alten Stettin, 1590, akwaforta, akwarela, papier, Muzeum Narodowe w Szczecinie (fot. Grzegorz Solecki\&Arkadiusz Piętak)

Widok ten miał na celu wyeliminowanie błędów i braków w obrazowej dokumentacji miasta kierowanej przede wszystkim do kupców, dyplomatów, 
podróżników4. W nowym wydaniu czwartego tomu Civitates orbis terrarum, opublikowanym w 1590 roku w języku niemieckim, na akwaforcie Alten Stettin ${ }^{5}$ szkoła nie tylko wygląda inaczej, ale ze względu na swe doniosłe znaczenie jako jeden z niewielu budynków na tym planie wyróżniona została podpisem: Pedagogium. Na tym skorygowanym planie Szczecina na północ od kościoła Mariackiego przedstawiono piętrową zabudowę tworzącą czworobok ${ }^{6}$. Budynek z okazałym portalem stojący wzdłuż ul. Mariackiej, to Duże Audytorium, które wzniesiono w 1550 roku na miejscu kapitularza i zachodniego krużganka. Po stronie północnej widoczne są dwa domy o różnej wysokości, zwrócone kalenicami w stronę murów miejskich. Nowy ciąg pomieszczeń powstał w rezultacie nadbudowy w latach 1563-1565 jednej kondygnacji nad krużgankiem północnym7. Mieściły one przedsionek i Małe Audytorium na parterze, a na piętrze pięć pokoi. Wzdłuż wschodniego skrzydła założenia, od strony Große Tumstrasse (obecnej ul. Farnej), widać piętrowy budynek z krużgankiem od strony dziedzińca. Ta forma albo niedokładnie odpowiada losowi wschodniego skrzydła krużganku, albo wskazuje, jak faktycznie wyglądało ono po przebudowie. Wiadomo bowiem, że skrzydło wschodnie, podobnie jak zachodnie, zostało w latach 1563-1565 nadbudowane o piętro wykonane w konstrukcji ryglowej (szachulcowej). Zostało zaopatrzone w okna od strony południowej, aby jak najwięcej światła dostarczały do wnętrza, ponieważ było przeznaczone na bibliotekę szkolną, funkcjonującą tu do 1781 roku. Być może forma skrzydła wschodniego świadczy, że zachowana część dawnego krużganka służyła jako korytarz umożliwiający komunikację między budynkami szkolnymi i kościołem. Na rycinie jest także widoczne wąskie południowe skrzydło krużganka istniejące tylko do 1677 roku. Autor widoku dość dokładnie przedstawił zabudowę szkoły, ale pominął istotną część tego założenia, czyli zabudowę służącą utrzymaniu nauczycieli i uczniów. O tym budynku pisze Scherbarth informując, że na terenie między kościołem i dawnymi domami kanoników, od strony ul. Mariackiej powstało nie tylko audytorium dla słuchaczy, ale i sala jadalna oraz zabudowa gospodarcza z kuchnią, które miały służyć profesorom

${ }^{4} \mathrm{O}$ celu publikacji autorzy piszą we wstępie do Georg Braun, Frans Hogenberg, Civitates orbis terrarum, t. 1: Liber quartus urbium praecipuarum...totius mundi (Coloniae Agrippinae: Georg Braun, 1588), 5-6.

5 Papier żeberkowy, 420 x $541 \mathrm{~mm}$, w zbiorach MNS odbitka kolorowana akwarelą, nr inw. MNS/Graf/2630.

${ }^{6}$ Opis krużganków i przekształceń założenia wykonał Fredrich, „Die ehemalige Marienkirche", 22-25.

${ }^{7}$ Daty budowy według Fredrich, „Die ehemalige Marienkirche”, 27. 
i uczniom ${ }^{8}$. Scherbarth podaje, że studenci stołowali się w szkole, a część z nich mieszkała na terenie założenia szkolnego zaplanowanego tak, aby mogło utrzymać 60 uczniów. Na zaktualizowanym widoku Hogenberga brak zatem przedstawienia północnego, rozbudowanego skrzydła krużganka, w którym mieściło się Małe Audytorium i pokoje mieszkalne, dokładnie opisane przez Fredricha. Widać natomiast ciąg budynków stojących wzdłuż ulicy przymurnej, złożonych z niższego, wąskiego domu i szeregu większych domów, w których w różnych okresach mieszkały osoby związane $\mathrm{z}$ funkcjonowaniem Fundacji Mariackiej i szkoły, między innymi kapelan, rektor, subrektor, inni nauczyciele?

Kolejne znane dokumenty ikonograficzne pochodzą z czasów, gdy Szczecin znajdował się pod panowaniem szwedzkim. Szwedzi opracowali dla Szczecina plany katastralne, stąd można by się spodziewać, że ich dokumentacja będzie w pełni wiarygodna. Plan Szczecina Stetin Ville forte d'Allemagne..., (Szczecin ufortyfikowane miasto niemieckie) według rysunku Harmanusa van Loona (?-?), rytował i wydał Nicolas de Fer (1646/164-1720) w Paryżu w 1691 roku, a wznowiono w 1693 i 1705 roku.

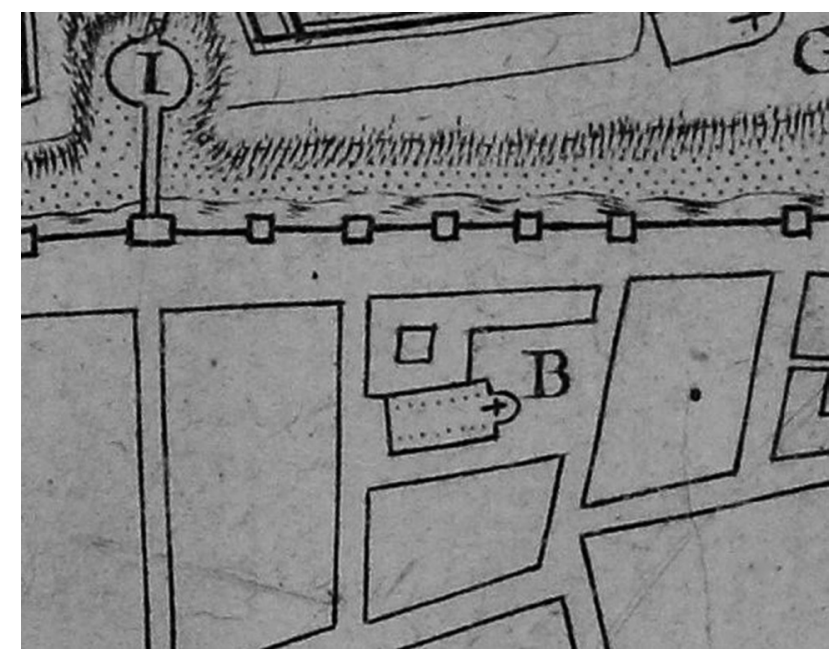

Rycina 2. Nicolas de Fer, według Harmanusa van Loona, kopia L. Scherm,

Plan Gimnazjum Carolinum, 1705 (1693), miedzioryt, papier, Muzeum Narodowe w Szczecinie (fot. archiwalna)

\footnotetext{
${ }^{8}$ Scherbarth, ,Zur Stiftung”, 75.

9 Fredrich, „Die ehemalige Marienkirche”, 32-33, 38-43.
} 
Kopię tego planu wykonał L. Scherm ${ }^{10}$. Założenie szkolne przedstawiono w uproszczony sposób, jako czworoboczną zabudowę, oznaczono ją literą B i opisano - Notre Dame (kościół Naszej Pani, czyli Mariacki). W okresie powstania planu szkoła nie była już Pedagogium, bowiem w 1667 roku zostało ono rozwiązane przez władze szwedzkie, które jednocześnie powołały Królewskie Gimnazjum Carolinum. Na planie van Loona i de Fera trzy skrzydła przebudowanych krużganków otaczają niewielki, kwadratowy dziedziniec wewnętrzny i łączą się bezpośrednio z biegnącym wzdłuż murów, aż do ul. Farnej, pasem zabudowy dawnych domów kanoników, czyli Domów Profesorskich. Od wschodniej strony założenia znajduje się zewnętrzny dziedziniec dostępny bezpośrednio z ul. Farnej.

Plan zawiera istotne braki i nieścisłości, przede wszystkim autor nie zaznaczył przebudowanego północnego skrzydła krużganków mieszczącego Małe Audytorium i pokoje mieszkalne na piętrze, a dziedzińcowi nadał formę regularną. Ważnym błędem było przedstawienie na planie południowego skrzydła krużganków, mimo że zostało zburzone podczas bombardowania brandenburskiego w 1677 roku. Co więcej, skrzydło to ukazane zostało jako oddalone od północnej nawy kościoła, do której wszak było przybudowane, na planie zatem tylko w ogólny sposób zaznaczono położenie szkoły.

Zniszczenia założenia szkoły od strony Domów Profesorskich obserwować można na jednym z rysunków dokumentacyjnych Abrahama Jansza Begeijna?, który relacjonował operacje wojsk brandenburskich podczas oblężenia Szczecina w 1677 roku. Na widoku miasta od północy, po bombardowaniu przeprowadzonym 16 i 17 sierpnia 1677 roku, kilka Domów Profesorskich pozbawionych jest dachów, pozostały natomiast ściany z wysokimi gotyckimi szczytami dzielonymi blendami. Niektórych zupełnie nie widać zza murów, z czego wynika, że także ściany uległy co najmniej częściowemu zniszczeniu ${ }^{11}$.

Następnie przez ponad dwieście lat szkoła związana była z państwem pruskim, które faktycznie przejęło Szczecin w 1713 roku. Jej bogata ikonografia z tego okresu nie tylko wynika z przebudów założenia i zmiany lokalizacji, z czym wiązało się powstawanie części dokumentacji. Świadczy przede wszystkim o wielkim znaczeniu i prestiżu szkoły oraz chlubie jaką przynosiła miastu.

\footnotetext{
${ }^{10}$ Miedzioryt, papier żeberkowy, 180 x $202 \mathrm{~mm}$, odbitka z 1691 roku w Landesarchiv Greifswald, nr inw. Rep. 55, Nr. 1a, 79; fotografia archiwalna w MNS, nr neg. MNS/AFoto/5043.

${ }^{11}$ Sepia, szary tusz, pióro, papier żeberkowy, 235 x $850 \mathrm{~mm}$, fotografia archiwalna w MNS, $\mathrm{nr}$ neg. MNS/AFoto/5125; reprodukcja w: Tadeusz Białecki, Szczecin na starych widokach (XVI-XX wiek). Stettin auf Alten Abbildungen (16.-20. Jahrhundert) (Szczecin: Archiwum Państwowe w Szczecinie, 1995): 254, il. 243.
} 
Już w pierwszym okresie panowania Hohenzollernów, w 1716 roku to jest w czasie, gdy Szczecin formalnie należał jeszcze do Szwecji, szkoła została przekształcona w Gimnazjum Akademickie, co wkrótce znalazło odzwierciedlenie w ikonografii. Jej obraz udokumentowano około 1725 roku, przed rozebraniem w tymże roku północnego odcinka średniowiecznych murów miejskich. Przedstawienie znalazło się na rycinie Georga Paula Buscha (4 ćwierć XVII - 1756 r.) ukazującej oba kościoły kolegiackie - św. Ottona i Mariacki. Ilustrowała ona jako frontyspis dzieło Johanna Samuela Heringa Historische Nachricht von der Stiftung der zwey Collegiat-Kirchen in der berühmten Stadt Alten Stettin, Alten Stettin 1725 (Historyczna relacja o fundacji dwu kolegiat w sławnym mieście Starym Szczecinie) ${ }^{12}$. Publikacja zawierała widok założenia ujęty od północy, zza murów miejskich, a więc od strony, która w XVIII wieku stała się zwyczajowym sposobem przedstawiania tego kompleksu szkolnego. Ponad koroną murów widoczne są trzypiętrowe, kilkuosiowe budynki, ustawione tak, jakby otaczały dziedziniec na rzucie trapezu. Można je określić następująco: po prawej stronie, przy ul. Mariackiej, główny gmach szkoły, równolegle do murów budynek Domów Profesorskich, oddzielony przerwą od szkoły zgodnie z faktem istnienia w tym miejscu przejazdu na dziedziniec, po lewej stronie, przy ul. Farnej budynek mieszczący bibliotekę szkolną. Taki obraz, mimo braku dokładności i ścisłości w oddaniu kształtu założenia, przekazywał ideę dyspozycji architektonicznej Gimnazjum Akademickiego.

Dokładne wyobrażenie szkoły i Domów Profesorskich pojawiło się kilkanaście lat później. Powstanie tego rysunku inwentaryzacyjnego wynikało z polityki urbanistycznej władz wobec Szczecina. Na północ od miasta zaplanowano założenie reprezentacyjnego placu parad, co wiązało się ze zburzeniem tego odcinka średniowiecznych murów miejskich. W następstwie tego kroku tylna elewacja Domów Profesorskich, zwrócona w stronę murów, musiała zostać przekształcona w elegancką fasadę. Nową fasadę, odpowiednią do znaczenia szkoły, zamierzano też nadać jej budynkowi. Konieczność przebudowy założenia poprzedzono sporządzeniem rysunku odzwierciedlającego stan aktualny oraz wstępnego projektu $^{13}$. Autorem tego dokumentu z 1739 roku był inżynier podporucznik Johann Friedrich Freund (czynny w XVIII wieku).

${ }^{12}$ Akwaforta, papier żeberkowy, 180 x 140 mm, Biblioteka MNS, sygn. S I 277; Gwiazdowska, Widoki, 207.

${ }^{13}$ Tusz, papier żeberkowy, brak wymiarów, fotografia archiwalna w MNS, nr inw. MNS/ AFoto/14744. 
Wygląd istniejących budynków przedstawiony został w dolnej partii karty podpisanej: Die anitzo befindliche Fronte der Prediger Häuser am Anklamer Thore (Elewacje Domów Kaznodziejów od strony Bramy Anklamskiej [obecnej Bramy Królewskiej]). Rysunek budynku administracyjno-gospodarczego, tak zwanej Ekonomii stojącej przy ul. Mariackiej, zajmował prawą dolną część arkusza.

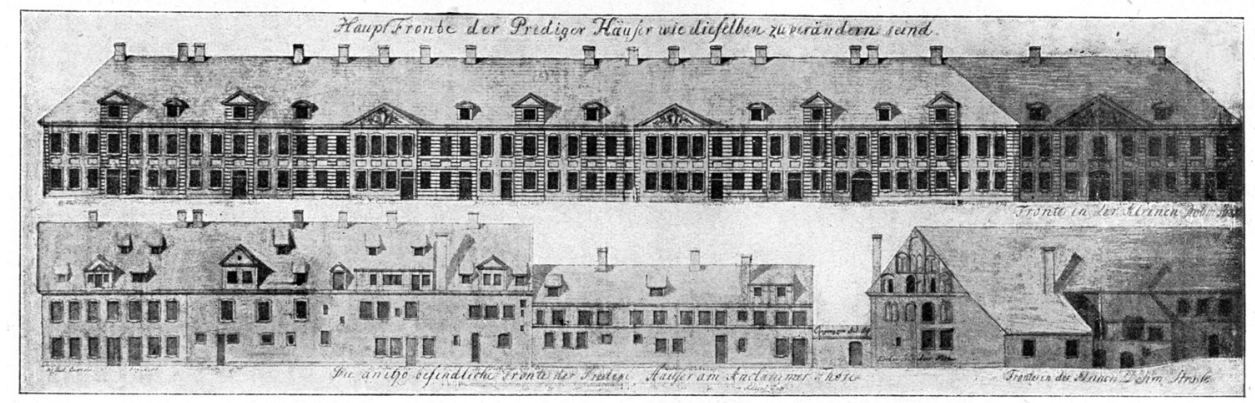

Rycina 3. Johann Friedrich Freund, Gimnazjum Akademickie, inwentaryzacja (u dołu) i projekt przebudowy (u góry), 1739, tusz, papier,

Muzeum Narodowe w Szczecinie (fot. archiwalna)

Ten piętrowy budynek od strony murów zachował jeszcze gotycką ścianę szczytową z szeregami okien i trzema kondygnacjami blend w szczycie, z których pewne wypełnione były oknami. Od strony ul. Mariackiej do Ekonomii przylegały dwie parterowe przybudówki świadczące o rosnącym zapotrzebowaniu na kolejne pomieszczenia niezbędne do funkcjonowania założenia szkolnego. W środkowej i lewej dolnej części karty rysownik pokazał wygląd Domów Profesorskich. Ta nieregularna zabudowa szeregowa, w której każda kamienica miała nieco inną dyspozycję, czyli rozmieszczenie otworów okiennych i drzwiowych oraz rozmaicie rozbudowane poddasze z różnego kształtu wystawkami usytuowanymi w jednej i dwu kondygnacjach, również sprawiała nieestetyczne wrażenie. Szczególnie jeśli wziąć pod uwagę ówczesny klasycyzujący gust, preferujący regularność, symetrię i harmonię całości architektonicznej.

Wygląd budynków świadczył za to o losach i życiu tego zespołu budowli. Niszczone w trakcie wojen wciąż odbudowywane i rozbudowywane w miarę, jak zmieniały się i rosły potrzeby mieszkańców, były świadectwem dziejów tej części miasta. W górnej partii karty opisanej jako Haupt Fronte der Prediger Häuser wie derselben zu verändert sind (Fasady Domów Kaznodziejów tak, jak mają być zmienione) Freund przedstawił projekt przebudowy domów, w ramach której 
miały być nie tylko ujednolicone gabaryty i fasady budynków. Tym ostatnim planował nadać nowy, klasycystyczny styl stosowny do ich zmienionej roli, jako pięknej, reprezentacyjnej oprawy nowego placu - jednego z dwóch placów parad założonych na splantowanych terenach odcinków średniowiecznych systemów obronnych $^{14}$. Od strony Placu Parad Freund planował wieloosiową, jednopiętrową fasadę dekorowaną tylko odcinkami rozmieszczonego pionowo boniowania. Zabieg ten miał przełamywać monotonię elewacji wypełnionej dwoma szeregami okien rozdzielonych prostokątnymi płycinami umieszczonymi pod oknami pierwszego piętra. Rytm tej elewacji nadawało pięć boniowanych osi zwieńczonych wystawkami z trójkątnymi szczytami, jedna na osi symetrii budowli (oś 25) i po dwie w bocznych odcinkach fasady (osie 4 i 10 licząc od węgłów) oraz dwa czteroosiowe pseudoryzality zwieńczone trójkątnymi frontonami (obejmujące osie 16-19 licząc od węgłów) flankujące oś symetrii fasady. Wejścia planowano rozmieścić niesymetrycznie w stosunku do osi wyróżnianych boniowaniem, z czego wynika, że ostateczny efekt estetyczny zostałby podporządkowany celowi utylitarnemu. Wydaje się to odpowiadać oświeceniowemu akcentowaniu użyteczności jako zalety podejmowanych przedsięwzięć. Klasycystyczną fasadę szkoły przy ul. Mariackiej miał zdobić trzyosiowy okazały fronton. Tympanony wszystkich frontonów Freund zamierzał wypełnić dekoracją reliefową. Plan zrealizowany został tylko częściowo ze względu na oszczędności podjęte w trakcie budowy przeprowadzonej w latach 1739-1742. Powodem była nowa polityka ekonomiczna wprowadzona przez Fryderyka Wielkiego, który w 1740 roku objął tron.

Faktyczny wygląd założenia od strony Domów Profesorskich przekazały widoki placu parad wykonane w czwartej ćwierci XVIII wieku. Chrystian Bischoff (? - 1775), profesor matematyki w Gimnazjum Akademickim w latach 1757-1774, wykonał rysunek panoramy Domów Profesorskich wraz z kościołem Mariackim w tle ${ }^{15}$. Widok ten datowany przez Carla Fredricha na około 1773-1775 rok znany jest także z kopii opracowanej piórem w tuszu przez J. Eduarda Schauera (?-?),

\footnotetext{
${ }^{14}$ Postawienie przy placu marmurowego pomnika Fryderyka II w 1793 roku skutkowało nazwaniem placu Weisse Paradeplatz (Białym Placem Parad), a przed 1828 plac został przemianowany na Königsplatz (Plac Królewski), por. plany Szczecina z 1820 i 1828 roku, reprodukcje w: Bogdana Kozińska, Rozwój przestrzenny Szczecina od początku XIX wieku do II wojny światowej (Szczecin: Muzeum Narodowe w Szczecinie, 2015): il. 2-3. Obecnie to pl. Żołnierza Polskiego.

${ }^{15}$ Brak danych technicznych, reprodukcja w: Karl Weishaupt, oprac. Deutschland Städtebau. Stettin (Berlin-Halensee: Deutscher Architektur- und Industrie Verlag, 1925), 31.
} 
zaopatrzonej w tytuł w rokokowym obramieniu: Eigentliche Scenographie der St. Marien Stifts-Kirche und der Prediger=Professoren bei dem Königl. Academischen Gymnasium und einigen andern Kirchenbedienten Wohnungen (Prawdziwe przedstawienie kościoła Fundacji Mariackiej i Domów Profesorskich przy Królewskim Gimnazjum Akademickim i kilku innych mieszkań sług kościelnych) ${ }^{16}$.

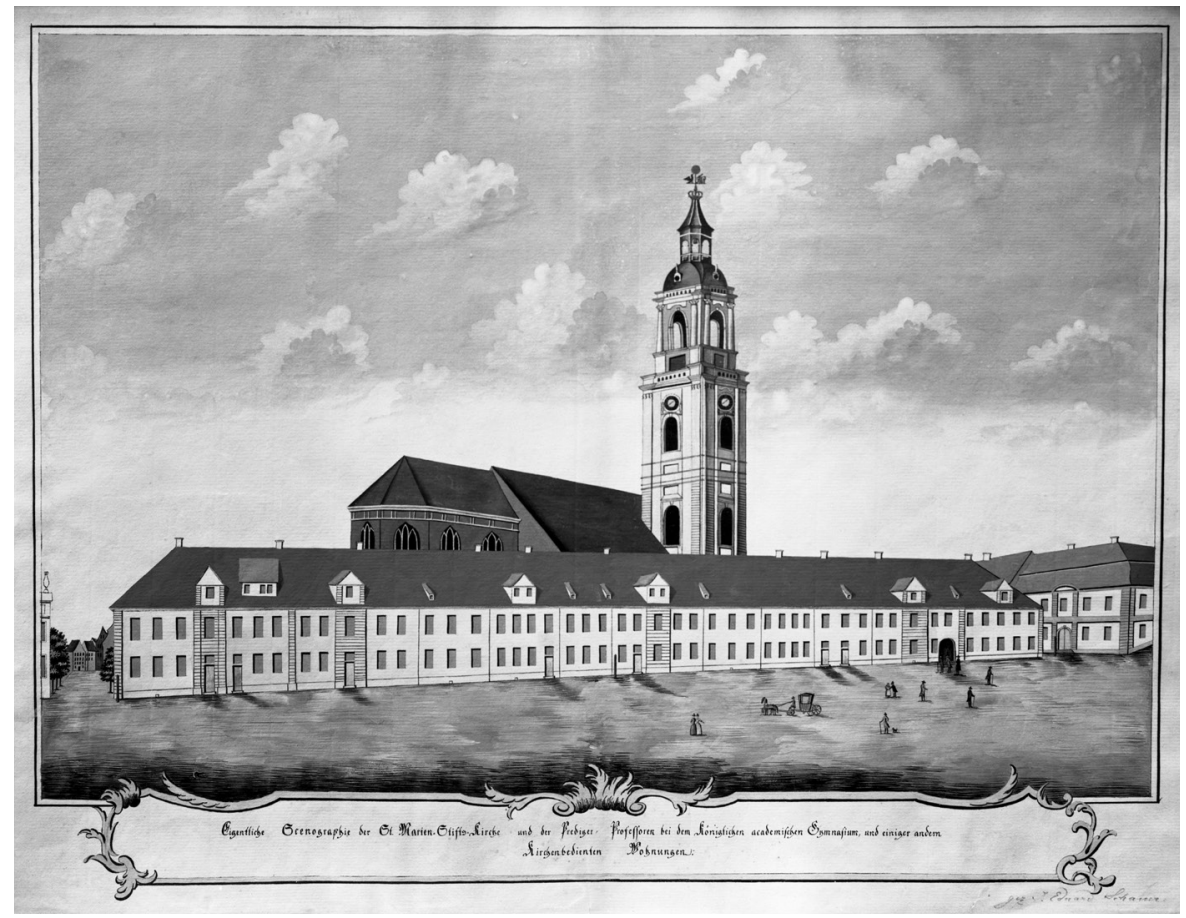

Rycina 4. J. Eduard Schauer, według Christiana Bischoffa, Panorama Domów Profesorskich, po 1775, pióro, pędzel, tusz, akwarela, papier, Muzeum Narodowe w Szczecinie (fot. archiwalna)

Widok świadczy o zmianach wprowadzonych w stosunku do projektu Freunda. Elewację zróżnicowano i wzbogacono tylko osiami zwieńczonymi wystawkami. Zamiast lewego ryzalitu z frontonem obejmującego osie 16-19, zbudowano wystawkę nad osią 17 i 18, ale wejście pozostawiono w 19 osi. Po prawej stronie budowli zrezygnowano nawet $\mathrm{z}$ wystawki zastępującej fronton. Formę zdobienia fasady szkoły zupełnie zmieniono (o czym szerzej w dalszej części tekstu).

${ }^{16}$ Tusz, akwarela?, pióro, pędzel, papier żeberkowy, 410 × $520 \mathrm{~mm}$, fotografia archiwalna w MNS, nr neg. MNS/AFoto/5139. Na temat losów tego rysunku Gwiazdowska, Widoki, 196. 
Perspektywicznie przedstawiona fasada Domów Profesorskich, z górującą nad nią świątynią Mariacką, przypomniana została przez Johanna Beniamina Glassbacha (?-?) po 1789 roku $^{17}$. Kompozycja Abbildung des St. Marien-Stifts-Kirche und des Thurms zu Stettin (Obraz kościoła i wieży Fundacji Mariackiej w Szczecinie) była już tylko wspomnieniem wyglądu placu, który po pożarze kościoła w owym roku stracił swoje historyczne piękno.

Zabudowa szkoły położona przy ul. Mariackiej została przedstawiona w ostatniej dekadzie XVIII wieku. Około 1790 roku motyw ten uwidocznił Friedrich August Scheureck (czynny w 4. ćwierci XVIII wieku) na jednej z cyklu akwafort poświęconych Szczecinowi: Ansicht der Thum Straße in Stettin gegen das Anclamer Thor (Widok ulicy Katedralnej w Szczecinie w stronę Bramy Anklamskiej) ${ }^{18}$. Był to perspektywiczny widok ulicy (obecnej Mariackiej) w stronę późniejszej Königstor, obecnej Bramy Królewskiej, zwanej też Bramą Hołdu Pruskiego. Przedstawienie jest jednak niewiarygodne, gdyż rytownik upodobnił fasadę szkoły do wyglądu kamienic stojących na południe od kościoła Mariackiego. Ukazał ją jako piętrową, z kondygnacjami rozdzielonymi gzymsem, i szeregiem okien mansardowych. Na lewo od szkoły Scheureck upamiętnił ruinę kościoła Mariackiego.

Kwestia stosownego do znaczenia szkoły wyglądu całego założenia powróciła pod koniec XVIII wieku. Przed odnowieniem ośrodka - poprzez położenie nowych tynków - udokumentowane zostały jego zewnętrzne elewacje. Rysunek inwentaryzacyjny Aufriß von denen zum Marien-Stifte gehörigen Kirchen Häuser... (Szkic domów kościelnych należących do Fundacji Mariackiej...) sporządził w 1799 roku krajowy budowniczy David Christlieb Meyer ${ }^{19}$.

${ }^{17}$ Miedzioryt, papier żeberkowy, 145 x 82 mm, fotografia archiwalna w MNS, nr neg. MNS/ AFoto/5142.

${ }^{18}$ Akwaforta konturowa, akwarela, papier żeberkowy, ok. 130 x ok. $210 \mathrm{~mm}$, fotografia archiwalna w MNS, nr neg. MNS/AFoto/5356. Reprodukcja w: Gwiazdowska, Widoki, 220-221, il. 43.

${ }^{19}$ Tusz, pióro, pędzel, papier żeberkowy, brak wymiarów, fotografia archiwalna w MNS, nr neg. MNS/AFoto/5147. 


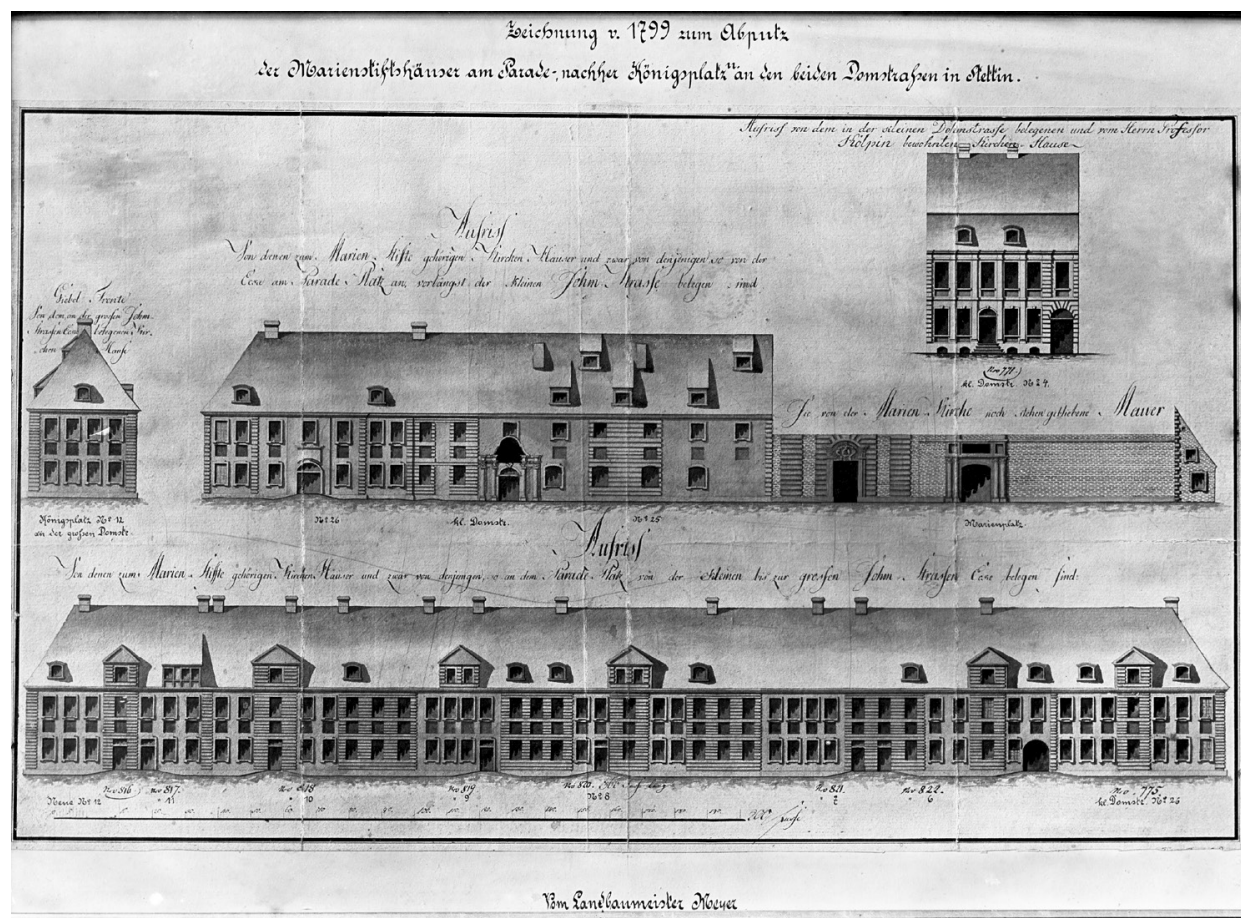

Rycina 5. David Christlieb Meyer, Gimnazjum Akademickie, inwentaryzacja założenia, 1799, pióro, pędzel, tusz, papier, Muzeum Narodowe w Szczecinie (fot. archiwalna)

Z jego rysunku wynika, że matematyk Bischoff ukazał Domy Profesorskie niezupełnie zgodnie $\mathrm{z}$ ich stanem faktycznym. Uwzględnił wszystkie wystawki, ale pominął odcinki boniowania przełamujące monotonię fasady poza osiami zaakcentowanymi wystawkami. $Z$ dokumentu Meyera znany jest również faktyczny wygląd budynków szkolnych, których fasady wychodziły na ul. Mariacką, a także elewacji szczytowej ściany domów profesorskich zwróconej na ul. Farną i fasada należącego do Fundacji Mariackiej domu przy ul. Mariackiej 4, naprzeciw szkoły, zamieszkiwanego przez prof. Kölpina. D.Ch. Meyer przedstawił budynek Dużego Audytorium jako sześcioosiowy, nakryty dwuspadowym dachem, o elewacji zróżnicowanej boniowaniem pokrywającym dwie osie środkowe. Gmach poprzedzony był w lewej skrajnej osi barokowym portykiem złożonym z par kolumn flankujących wejście i dźwigających półkoliste, łamane zwieńczenie. Rafał Makała podaje, że portyk wybudowano w 1744 roku i przypuszcza, że w jego 
zwieńczeniu znajdowały się „herby królewskie” ${ }^{20}$. W fasadzie znajdowały się dwie kondygnacje okien ujętych w płaskie opaski. Osie okienne zaakcentowane były kwadratowymi płycinami. Szereg okien parteru zamkniętych łukami odcinkowymi wskazywał położenie głównej sali wykładowej - Dużego Audytorium. W dachu znajdowały się dwa rzędy okien. Liczba i rozmieszczenie wszystkich okien świadczą o tym, jak intensywnie budynek był eksploatowany. Sąsiadujący ze szkołą dziewięcioosiowy budynek administracyjny - Ekonomia - miał podobną dyspozycję fasady, przy czym był zdobiony boniowaniem rozmieszczonym tak, by mogło wprowadzać element harmonii do całości tworzonej przez oba gmachy. Temu zadaniu podporządkowane było także usytuowanie arkadowego portalu prowadzącego do Ekonomii. Poddasze budynku oświetlane było tylko przez jeden rząd okien. Elewacja szczytowa Domów Profesorskich miała dyspozycję analogiczną jak fasady gmachów przy Mariackiej. Natomiast z rysunku D.Ch. Meyera wynika, że ruina kościoła została już rozebrana i pozostał tylko pas muru przyziemia wraz z dwoma portalami.

Źródłem informacji o rzucie założenia Gimnazjum Akademickiego jest plan inwentaryzacyjny Grundriß sämtlicher dem Marien Stifte zugehörigen Gebäude (Plan wszystkich budynków należących do Fundacji Mariackiej) wykonany w 1804 roku, podpisany nieczytelnie ${ }^{21}$.

Według tego rysunku budynki Dużego Audytorium oraz przebudowane północne i wschodnie skrzydła krużganku tworzyły regularne, trójskrzydłowe otoczenie dawnego wirydarza. Na parterze skrzydła północnego znajdował się przejazd na ten dziedziniec. Budynek Ekonomii zajmujący naroże ul. Mariackiej i pl. Żołnierza Polskiego miał kształt nieregularnego trapezu. Wąski przejazd oddzielał go wyraźnie od Domów Profesorskich, których zachodni odcinek pozostał ,wąskim domem”, natomiast we wschodnim odcinku poszczególne budynki miały zróżnicowaną głębokość i wielkość przyległych działek gospodarczych. Co ciekawe, między rysunkiem inwentaryzacyjnym Meyera z 1799 roku i tym z 1804 roku brak zgodności w liczbie osi okiennych budynków stojących przy ul. Mariackiej, choć osi tych było stosunkowo niewiele. Natomiast na obu rysunkach zaznaczono tę samą liczbę osi w fasadzie Domów Profesorskich.

\footnotetext{
${ }^{20}$ Konturowy zarys formy tego portyku opublikował Carl Fredrich. Rafał Makała, „Gimnazjum Mariackie”, w: Maciej Słomiński, Rafał Makała, Małgorzata Paszkowska, Szczecin barokowy. Architektura lat 1630-1780 (Szczecin: Stowarzyszenie Historyków Sztuki Oddział w Szczecinie, 2000), 117, 119, il. 55.

${ }^{21}$ Tusz, pióro, papier żeberkowy, brak wymiarów, fotografia archiwalna w MNS, nr neg. MNS/ AFoto/5134.
} 


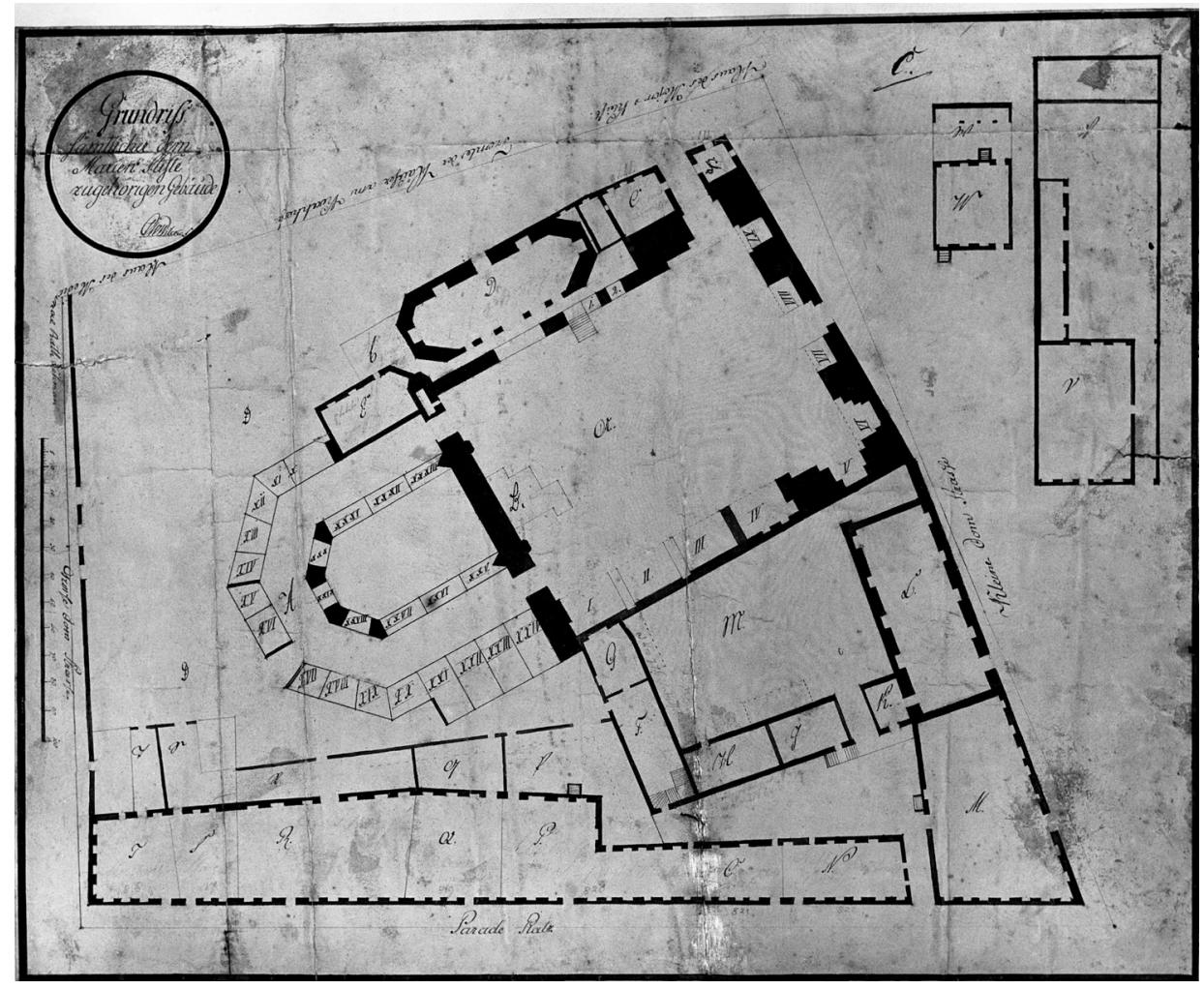

Rycina 6. Podpis autora nieczytelny, Plan założenia szkolnego i kościoła Mariackiego, rysunek inwentaryzacyjny, 1804, tusz, papier, Muzeum Narodowe w Szczecinie (fot. archiwalna)

Widok biblioteki szkolnej przeniesionej w 1781 roku do przebudowanego w tym celu wnętrza gotyckiej kaplicy Mariackiej, przylegającej do południowej nawy kościoła Mariackiego, znany jest dzięki cyklowi trzech miedziorytów Friedricha Ludwiga Kirchhoffa (ok. 1750 - po 1804?), na których rytownik relacjonował pożar świątyni w 1789 roku $^{22}$. Jak wynika z tych rycin, do przebudowy elewacji kaplicy projektowanej w latach 1778-1781 nie doszło ${ }^{23}$.

${ }^{22}$ Prospect der St. Marie Stifts. Kirche (...) (Widok kościoła Fundacji Mariackiej), miedzioryty, papier żeberkowy, po 310 x $145 \mathrm{~mm}$, fotografie archiwalne w MNS, nr neg. MNS/AFoto/5140A i 5141; Gwiazdowska, Widoki, 227-229, il. 46.

${ }^{23}$ Przerys wykonany przez Fredricha reprodukowany w: Makała, „Gimnazjum”, 120. 


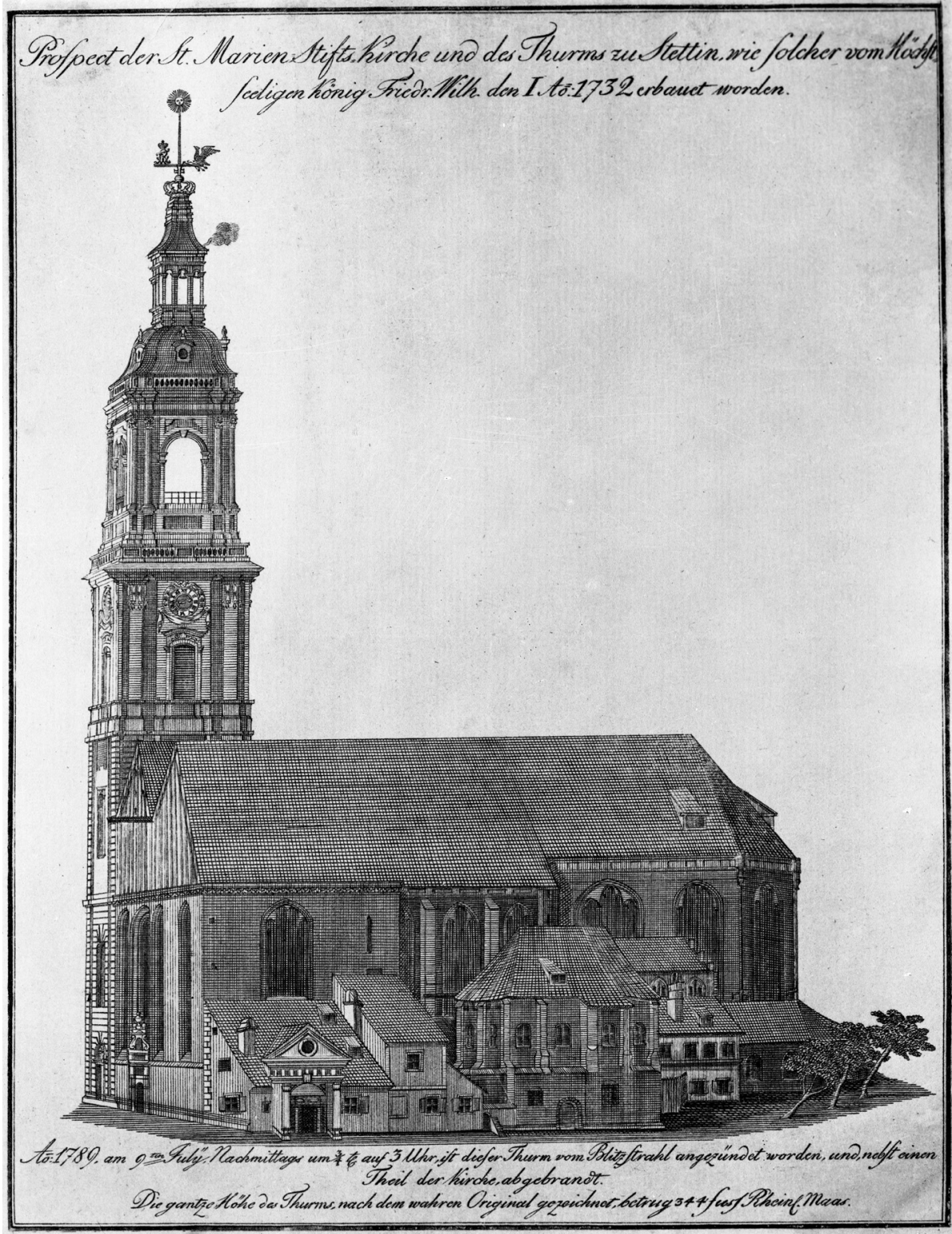

Rycina 7. Friedrich Ludwig Kirchhoff, Kościół Mariacki od strony południowej z kaplicą Mariacką mieszczącą bibliotekę Gimnazjum Akademickiego, 1789, miedzioryt, papier, Muzeum Narodowe w Szczecinie (fot. archiwalna)

Pisząc o ikonografii szkoły Mariackiej warto uwzględnić widok założenia mieszczącego Liceum Miejskie, ponieważ w pewnym okresie, od 1805 do 1869 roku, obie szkoły były połączone jako Königliches- und Stadtgymnasium 
(Królewskie i Miejskie Gimnazjum) i częściowo funkcjonowały w tym samym budynku. Uczniowie klas młodszych, od szóstej do czwartej, mieli zajęcia w szkole miejskiej przy Mönchenstrasse (obecnej ul. Grodzkiej). Dobrym świadectwem wyglądu jej siedziby jest rycina Friedricha Ludwiga Kirchhoffa Ansicht des Lyceums zu Stettin (Widok Liceum w Szczecinie) ilustrująca jubileuszową publikację poświęconą szkole miejskiej z okazji jej czterechsetnego jubileuszu ${ }^{24}$.

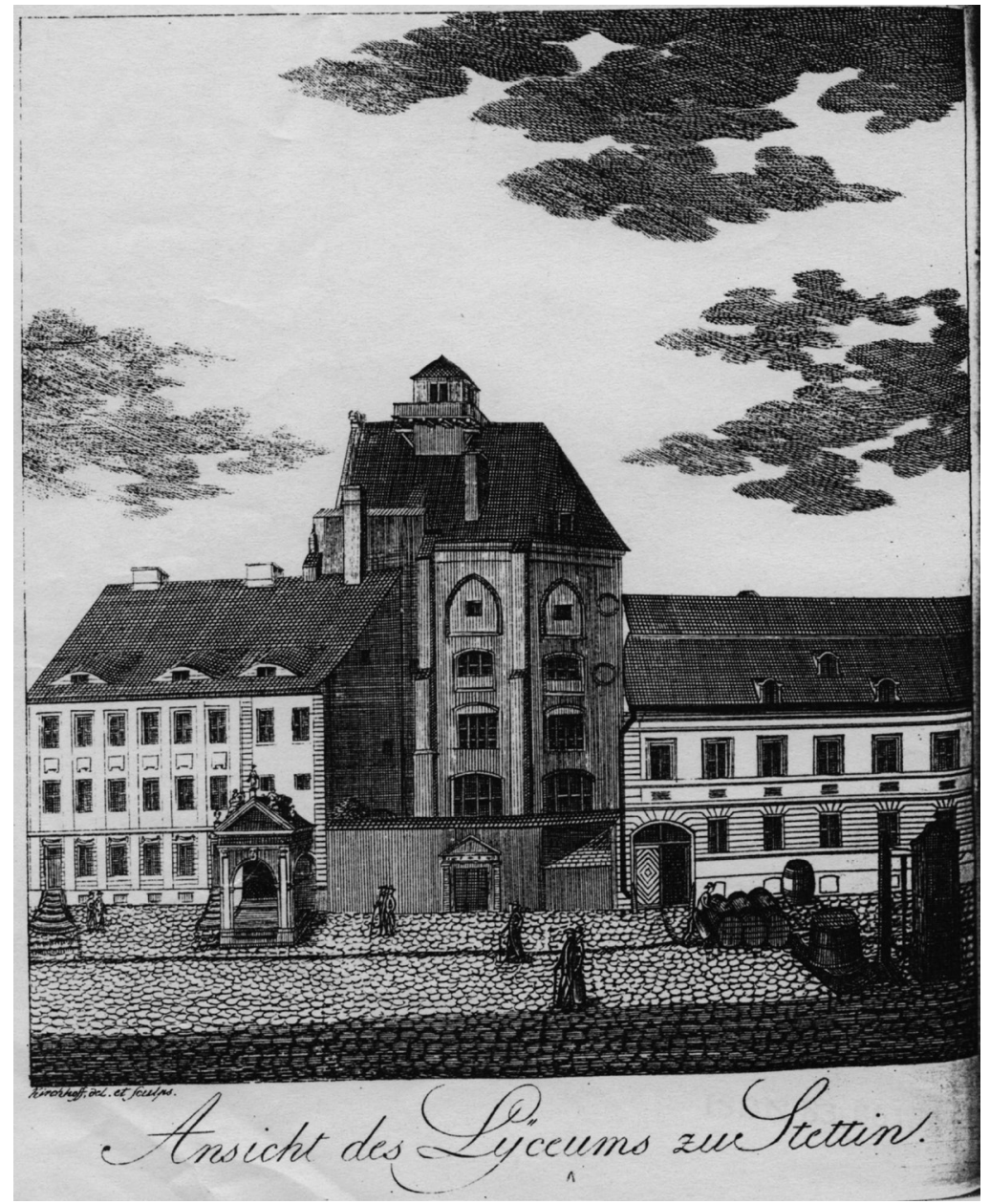

Rycina 8. Friedrich Ludwig Kirchhoff, Liceum Miejskie, w latach 1805-1832 również siedziba Gimnazjum Mariackiego, 1804, miedzioryt, papier, Muzeum Narodowe w Szczecinie (fot. Grzegorz Solecki\&Arkadiusz Piętak)

${ }^{24}$ Miedzioryt, papier żeberkowy, 197 x 170 mm, MNS, nr inw. MNS/Graf/2632; Gwiazdowska, Widoki, 229-230, il. 47. 
Widok stanowił frontyspis dzieła Friedricha Kocha, Geschichte des Lyceums zu Stettin; erste Periode von 1404 bis 1578, Stettin 1804 (Dzieje Liceum w Szczecinie, pierwszy okres od 1404 do 1578). Szkoła funkcjonowała w gotyckim prezbiterium, pozostałym po rozpoczętej przez karmelitów budowie kościoła św. Anny. Prezbiterium to zostało wewnątrz podzielone na kondygnacje, a na dachu zbudowano belweder mieszczący obserwatorium astronomiczne. Do dawnego prezbiterium dobudowano w XVIII wieku dwa wieloosiowe skrzydła, każde z osobnym wejściem. Do lewego budynku, dwupiętrowego, prowadził arkadowy portyk, zwieńczony trójkątnym frontonem zdobionym rzeźbami, mieszczący schody oraz boczne wejście. Okna parteru tego skrzydła upiększono nadokiennymi festonami. Fasady obu skrzydeł dzielone były boniowaniem i urozmaicone płycinami.

Intrygującym informacyjnie źródłem jest rzut założenia gimnazjum znajdujący się na planie Szczecina wykonanym w 1811 roku przez F.D.C. Josta (?-?), a uzupełnionym w 1820 roku przez Kummera, Grundriss der Stadt Stettin, innerhalb den Festungswerken und deren neuen Bezirks-Eintheilungen (Plan miasta Szczecina w obrębie fortyfikacji wraz z podziałem na dzielnice ${ }^{25}$. Na tym planie przedstawiono wszystkie istniejące $\mathrm{w}$ owym czasie budynki założenia z zaznaczeniem położenia dawnego Dużego Audytorium. $\mathrm{Z}$ tego dokumentu wynika, że rozmieszczenie przestrzenne głównych budynków odpowiadało temu, które w 1725 roku przedstawił G.P. Busch na omawianej wyżej rycinie ilustracyjnej w dziele S. Heringa. Widać, że zachodnie i wschodnie skrzydło założenia ustawione są względem siebie pod kątem rozwartym. Różnica między obu źródłami: widokiem i planem zasadza się na długości budynku stojącego od strony północnej. Szereg Domów Profesorskich jest na planie dużo dłuższy niż budynek ukazany przez Buscha. Jeśli założymy, że celem Buscha było pokazanie jedynie siedziby szkoły, to na XIX-wiecznym planie odpowiednikiem budynku ukazanego przez Buscha od północy mógłby być jedynie gmach mieszczący Małe Audytorium.

Powstanie zupełnie nowej siedziby szkoły, wzniesionej w 1832 roku na miejscu rozebranych ruin kościoła Mariackiego, zaowocowało pojawieniem się obfitej ikonografii tego gmachu. Przede wszystkim były to rysunki projektowe wykona-

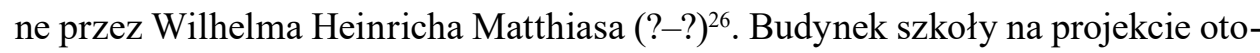

\footnotetext{
${ }^{25}$ Brak danych technicznych, Kozińska, Rozwój, il. 3.

${ }^{26}$ Pisze o tym Bogdana Kozińska, reprodukując rysunki projektowe, taż, ,«Młodzieży dla wychowania w dobrych obyczajach» Opis nowego budynku szczecińskiego Gimnazjum Mariackiego
} 
czony był wygrodzonym parkiem w stylu angielskim. Ta idealizowana lokalizacja w rzeczywistości nie została zrealizowana, a raczej była tylko konwencjonalnym przedstawieniem. Dzięki zachowanym rzutom i przekrojom poszczególnych kondygnacji wiadomo, jak obszerny program edukacyjny miała realizować szkoła. Z okazji otwarcia placówki berlińska firma J. Storcha wydrukowała zaproszenie z rozbudowaną okolicznościową szatą graficzną. Pamiątkowy druk ozdobiono litografią S.E. Hoffmanna (?-?) z widokiem Królewskiego i Miejskiego Gimnazjum od strony fasady, czyli od strony Marienplatz (obecnego pl. Mariackiego) oraz rzutami dwu głównych kondygnacji ${ }^{27}$.

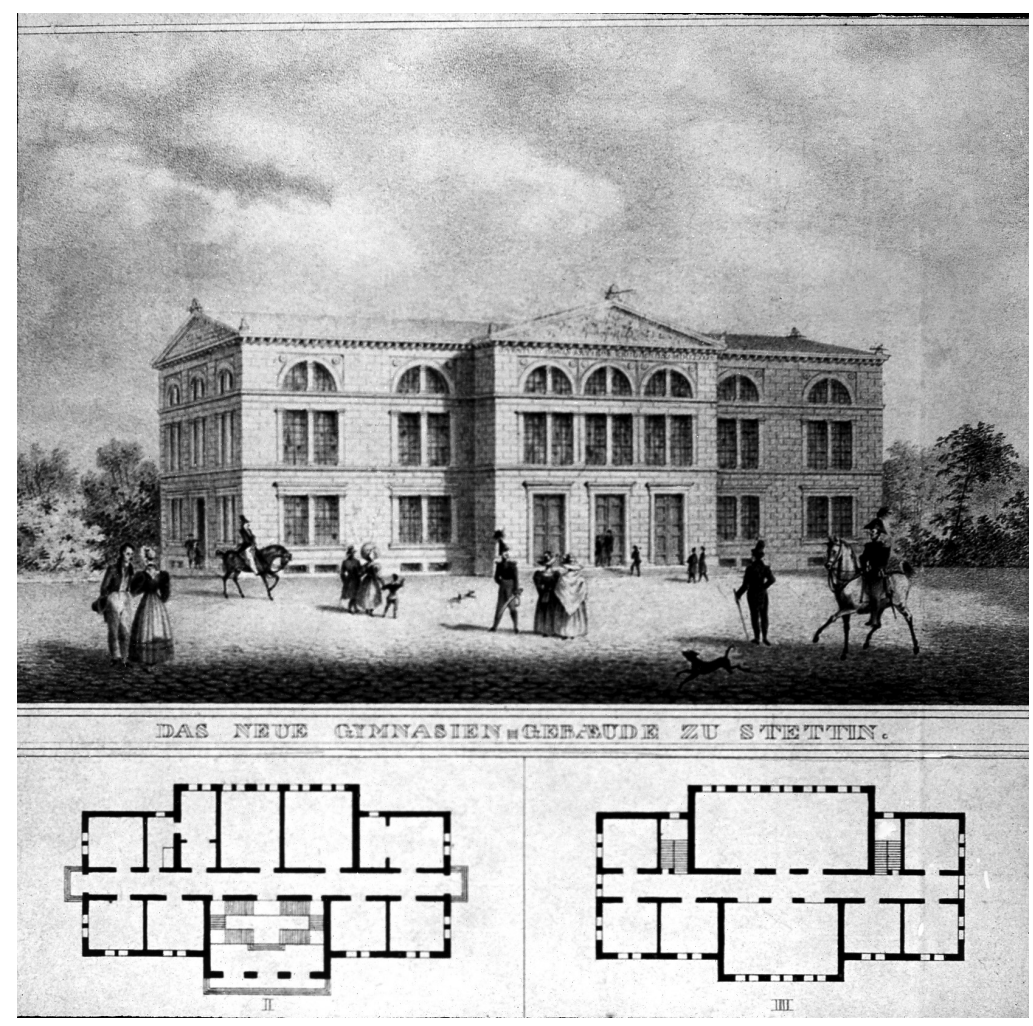

Rycina 9. S.E. Hoffmann, Widok i rzuty budynku Gimnazjum Mariackiego z 1832, 1832, litografia, papier, Muzeum Narodowe w Szczecinie (fot. archiwalna)

sprzed 180 lat”, Szczeciner. Magazyn miłośników Szczecina 2 (2012): 165-171, w artykule opartym na tłumaczeniu tekstu Carla Friedricha Wilhelma Hasselbacha wydrukowanego w Sundine. Unterhaltungsblatt für Neu-Vorpommern und Rügen 49 (6 XII 1832): 387-389.

${ }^{27}$ Brak danych o papierze i wymiarach; fotografia archiwalna w MNS, nr neg. 14746. Kozińska, „Młodzieży”, 171. 
Fasadę dwupiętrowego, klasycystycznego gmachu poprzedzał trójosiowy portyk zwieńczony trójkątnym frontonem zdobionym płaskorzeźbą i akroterionami. Portyk ten przypominał ów, na który zabrakło funduszy podczas XVIII-wiecznej przebudowy szkoły ${ }^{28}$. Osie okienne zwieńczone półkoliście tworzyły optyczne jedności na całej wysokości fasady, mimo podziału gzymsami kordonowymi. Hoffmann ukazał wokół szkoły spory ruch uliczny - uczniowie spieszą na lekcje, na spacer, aby obejrzeć i podziwiać okazałą architekturę, wybrali się bogaty młodzieniec jadący konno oraz piesi mieszczanie, którzy zatrzymują się, by wymienić uwagi ze znajomymi. Na placu pojawiają się także przedstawiciele miejscowego garnizonu, którzy stanowili spory procent mieszkańców Szczecina i nadawali ton stolicy Prowincji Pomorze.

Nowy obiekt architektoniczny stał się jednym z najważniejszych powodów do dumy i godnych upamiętniania budynków publicznych w mieście. Jego znaczenie dało asumpt do stworzenia wielu pamiątkowych widoków graficznych i ceramicznych. Przede wszystkim widok gmachu stał się motywem luksusowych, wieloelementowych przedstawień Szczecina zwanych wedutami zbiorowymi (Sammelvedute). Pierwszą z nich - Stettin - w 1834 zaprojektował August Ludwig Most (1807-1883), wykonał E. Scharden (?-?), a wydał w 1836 roku w Berlinie Königliches Lithographisches Instytut ${ }^{29}$. Obraz gimnazjum, ujętego od południowego zachodu, umieszczony został na bordiurze, po prawej stronie u góry, pod widokiem zamku królewskiego, dawnego zamku Gryfitów, a więc w polu ważnym symbolicznie.

Drugą kompozycję tego rodzaju opracował Gustav Frank (czynny w 3. ćwierci XIX wieku) około $1860 \mathrm{roku}^{30}$. Jego przedstawienie szkoły, ukazanej od południowego wschodu, umieszczone na weducie Stettin mit Umgebungen (Szczecin wraz z okolicami) wydanej także przez Königliches Lithographisches Instytut w Berlinie również znalazło się w ważnym polu, w górnej części bordiury, na prawo od zamku. Na obu omawianych litografiach sztafaż jest dość schematyczny. U Franka, na co warto zwrócić uwagę, po prawej stronie pojawił

\footnotetext{
${ }^{28}$ Niestety na wymienione zdobienia również w XIX wieku zabrakło środków finansowych.

${ }^{29}$ Litografia, papier welinowy, wymiar przedstawienia 430 × $560 \mathrm{~mm}$, Kupferstichkabinett. Sammlung der Zeichnungen und Druckgraphik Staatliche Museen Berlin Preußischer Kulturbesitz. Reprodukcja w: August Ludwig Most. Pomorski artysta epoki biedermeieru. Der Pommersche Künstler der Biedermeierzeit, red. Ewa Gwiazdowska, Rafał Makała (Szczecin: Muzeum Narodowe w Szczecinie, 2007), 223.

${ }^{30}$ Litografia barwna, papier, 344 x 506 mm; Greifswald, Pommersches Landesmuseum. Reprodukcja w: Białecki, Szczecin, 79, il. 53.
} 
się widok fragmentu Domów Profesorskich oddzielonych niskim budynkiem gospodarczym od terenu szkoły.

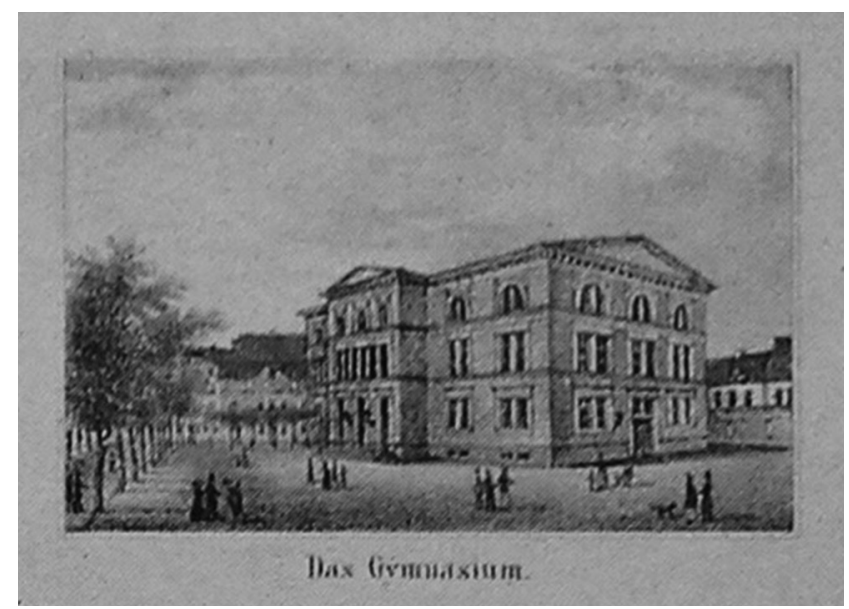

Rycina 10. Gustav Frank, Widok Gimnazjum Mariackiego, ok. 1860, litografia, papier, faksymile, Muzeum Narodowe w Szczecinie

Charakterystyczna forma architektoniczna gimnazjum zbudowanego na planie krzyża, a także szereg Domów Profesorskich są łatwo rozpoznawalne na rycinie Stettin - widoku Szczecina z lotu ptaka - stalorycie Williama Frencha (ok. 1815-1898) według rysunku Adolpha Eltznera (1816-1891), opublikowanym około 1851 roku przez oficynę spadkobierców Alberta Henry’ego Payne’a czynną w Dreźnie i Lipsku³.

Biedermeierowskie porcelanowe filiżanki zdobione motywem szkoły Fundacji Mariackiej z podpisem Gymnasium in Stettin produkowane były już od początku jego funkcjonowania. Przekonuje o tym pamiątkowe naczynie z kolekcji Hannelore Kramp pochodzące z Sanitäts- und Steingutfabriken Carl Krister w Waldenburgu (Wałbrzychu), opatrzone znakiem firmowym stosowanym w latach 1831-184032. W latach sześćdziesiątych XIX wieku Królewska Manufaktura Porcelany w Berlinie produkowała serie talerzy ozdobionych na lustrze

${ }^{31}$ Papier, 235 x 367 mm, MNS, nr inw. MNS/Graf/4031 i 4107. Reprodukcja w: Gwiazdowska, Widoki, 292.

${ }^{32}$ Malarstwo naszkliwne, wys. filiżanki $70 \mathrm{~mm}$, Hans Herbert Krause, oprac. „Stettin auf Weißem Gold. Veduten auf Porzellan des 18. und 19. Jahrhunderts”, Stettiner Heft 20 (2017). Lübeck: Historischer Arbeitskreis Stettin, 2017: 46. 
motywem tejże szkoły z podpisem: Gymnasium ${ }^{33}$. Porównanie kompozycji na filiżance i talerzach z litografią opracowaną przez Franka prowadzi do wniosku, że wszystkie one miały wspólny, nierozpoznany dotychczas pierwowzór graficzny bądź malarski.

Ujęcie zastosowane od przeciwnej, południowo-zachodniej strony geograficznej spotykane jest natomiast w kilku wariantach różniących się kątem patrzenia na upamiętnianą budowlę. U S.E. Hoffmanna jest ono bardziej prostopadłe w stosunku do fasady. A.L. Most przyglądał się gmachowi, stojąc bliżej jego węgła, podobnie jak anonimowy autor niedatowanego rysunku pędzlem i pió$\mathrm{rem}^{34}$. Kompozycja Mosta najprawdopodobniej ozdobiła dekoracyjne Tableau GYMNASII SEDINENSIS COLLEGIUM FRANCISCO KERN (Tableau Kolegium Franza Kerna w Gimnazjum Szczecińskim) ${ }^{35}$ z portretami nauczycieli gimnazjum, pośród których znalazło się także popiersie Mosta uczącego w tej szkole rysunku (od grudnia $1841 \mathrm{roku})^{36}$.

Całkowicie prostopadle przedstawił w 1869 roku fasadę Gimnazjum Fundacji Mariackiej Robert Geissler (1819-1893), rysując litografię do cyklu 24 widoków Szczecina zebranych w Album von Stettin, wydanym przez szczecińską oficynę Verlag von Danneberg und Dühr ${ }^{37}$.

A.L. Most jest autorem jedynego znanego widoku wnętrza gimnazjum. W 1854 roku odchodził na emeryturę dyrektor Carl Friedrich Wilhelm Hasselbach (1781-1864). Most podarował mu na pamiątkę cykl akwarel, pośród których obok przedstawienia gimnazjum i placu Mariackiego był widok pokoju konferencyjnego ${ }^{38}$.

\footnotetext{
${ }^{33}$ Malarstwo naszkliwne, średnica talerza 215 mm, Krause, „Stettin”, 98, 111.

${ }^{34}$ Brak danych technicznych, fotografia archiwalna, MNS, nr neg. MNS/AFoto/5148.

${ }^{35}$ Fraz Georg Kern (1830 Szczecin - ok. 1900 Berlin) nauczyciel; od 1852 pracował w Gimnazjum Fundacji Mariackiej, a od 1882 - w Gimnazjum Miejskim.

${ }^{36}$ Fotomontaż, niedatowany, fotografie, tusz, papier, brak wymiarów, fotografia archiwalna, MNS, nr neg. MNS/AFoto/5148.

${ }^{37}$ Litografia na tonowanym tle, papier kredowy, 76 x 116 mm, MNS, nr inw. MNS/Graf/4038. Reprodukcja w: Białecki, Szczecin, 315, il. 347.

${ }^{38}$ Papier, brak wymiarów, fotografia archiwalna, MNS, nr neg. MNS/AFoto/16124.
} 


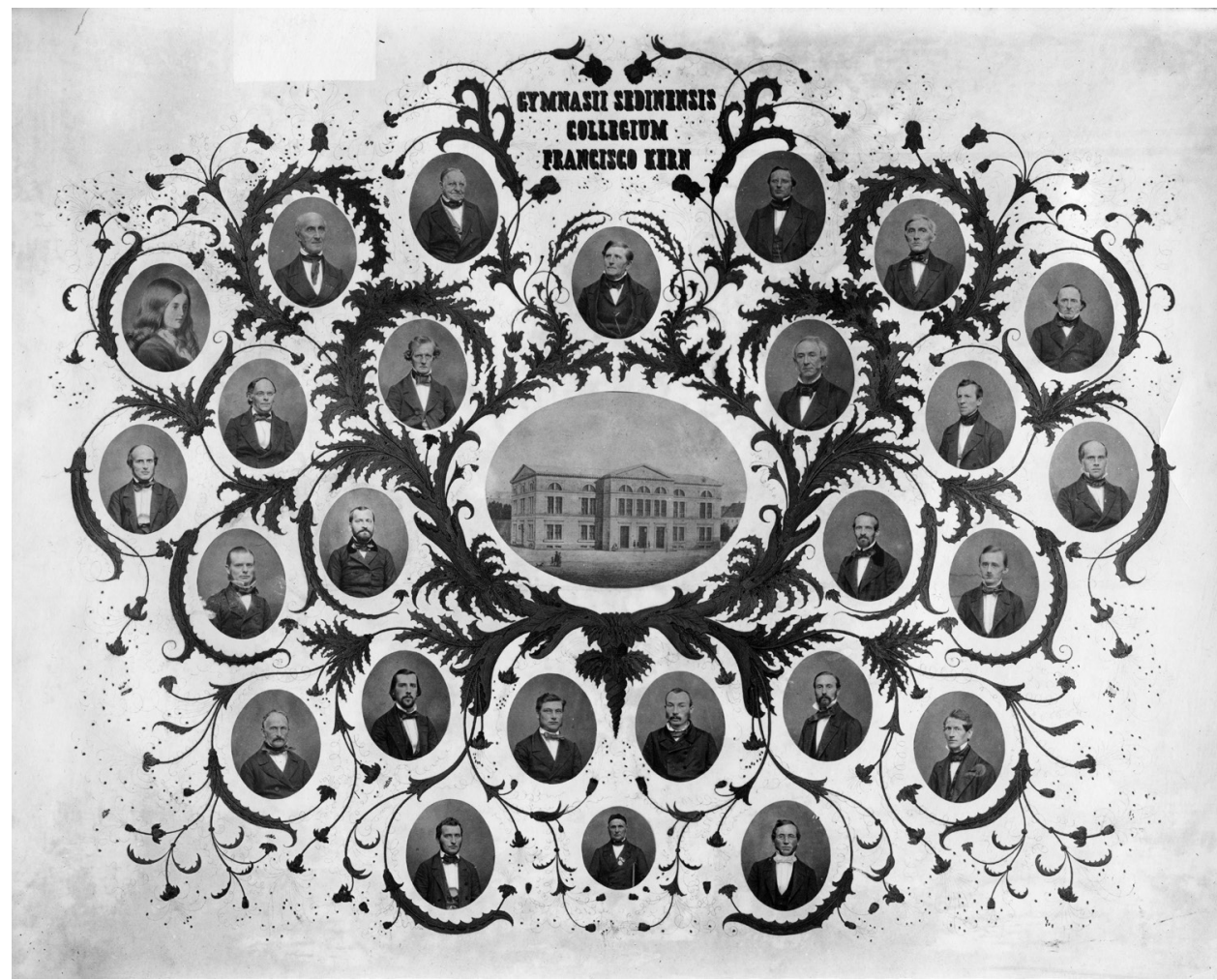

Rycina 11. Autor anonimowy, Tableau Gimnazjum Mariackiego, po 1852, fotografia, papier, Muzeum Narodowe w Szczecinie (fot. archiwalna)

Most udokumentował wnętrze, w którym nauczyciele zbierali się na spotkania przy stole. Pokój był miejscem wyjątkowym w przestrzeni szkoły. Całą wysokość szczytowej ściany zajmował symboliczny obraz Friedricha Georga Weitscha (1758-1828) przedstawiający Przysięge stanów przy ottarzu ojczyzny, namalowany w 1814 roku. Ponadto na ścianach zawieszono 14 innych obrazów, z których większość stanowiły portrety. Były to konterfekty władców Prus, dobroczyńcy szkoły Ewalda Friedricha hrabiego von Hertzberga (1725-1795), dawnego nauczyciela Johannesa Micraeliusa (1597-1658) oraz nauczycieli współczesnych A.L. Mostowi malowane przez niego samego ${ }^{39}$. Przy ścianach pokoju stały szafy biblioteczne zwieńczone antycznymi popiersiami. Takie wyposażenie odwoływało się do ideałów przyświecających szkole wychowującej w duchu

\footnotetext{
${ }^{39}$ Kozińska wymienia te obrazy opierając się na danych z Fremdenführer durch Stettin, Swinemünde, Heringsdorf, Misdroy und Rügen (Stettin: Ferd. Muller \& Co [1847]), 30, taż, „Młodzieży”, 170. Za dodatkową informację o źródle danych serdecznie dziękuję dr Bogdanie Kozińskiej.
} 
neohumanizmu - patriotyzmu, antycznego wzorca i szacunku dla autorytetów. Problemem, w przypadku tego przedstawienia, jest ustalenie, które pomieszczenie Most malował. Przedstawiona sala, określona jako pokój konferencyjny, nie odpowiada pomieszczeniu widocznemu na projekcie Matthiasa, gdyż u Mosta drzwi znajdują się naprzeciw okien ${ }^{40}$ - bliższa jest rzutowi pokoju nauczycielskiego na tym samym projekcie. Jednak i tu można dostrzec różnicę, gdyż Most ukazał drzwi do sali pośrodku ściany, a na projekcie znajdują się one blisko jej narożnika ${ }^{41}$. Wygląda na to, że artysta ze względów estetycznych posłużył się niewielkim zniekształceniem malowanego motywu.

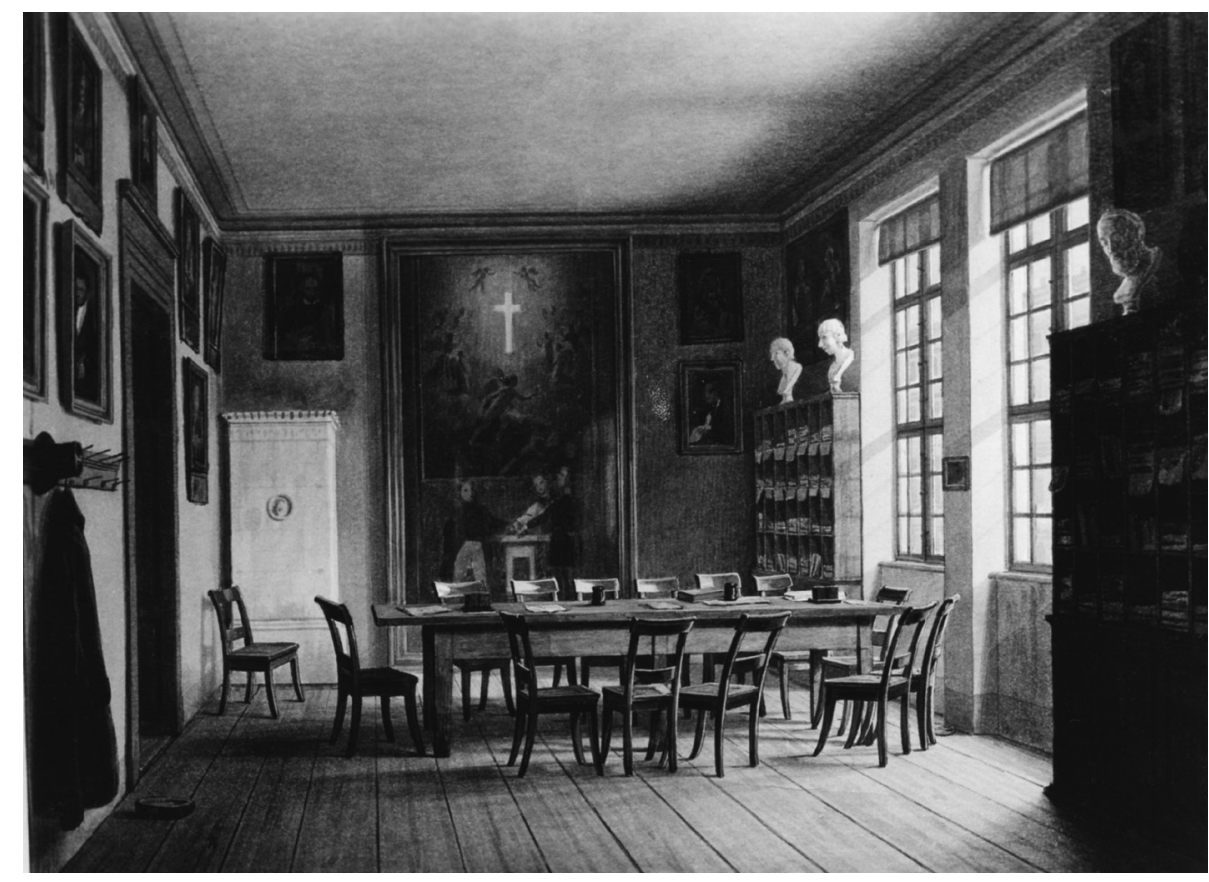

Rycina 12. August Ludwig Most, Gimnazjum Mariackie, widok pokoju nauczycielskiego, 1854, akwarela, papier,

Muzeum Narodowe w Szczecinie (fot. archiwalna)

Skrócone obrazowe dzieje Gimnazjum Fundacji Mariackiej zawarł na czterowidokowym drzeworycie E. Fobke (?-?), wykonując ilustrację do poświęconej

${ }^{40}$ Nazwa pokoju podana w katalogu wystawy, na której akwarela była prezentowana, Otto Holtze, oprac., Das Stadtbild Stettins vom 16. Jahrhundert bis zur Gegenwart in Gemälden, Zeichnungen und Bilddrucken der Zeit. Ausstellung veranstaltet vom..., Stettin: Museum der Stadt Stettin vom 18. Oktober bis 15. November 1936 (Stettin: Museum der Stadt Stettin, 1936), poz. 132.

${ }^{41}$ Por. reprodukcja projektu w: Kozińska, ,Młodzieży”, 166. 
szkole jubileuszowej publikacji, opracowanej na jej 350-lecie. Na drzeworycie zamieszczonym w dziele Martina Wehrmanna, Festschrift zum freihundertfünfzigjährigen Jubiläum des Königlichen Marienstifts-Gymnasiums zu Stettin 1544-1894. Stettin: Herrcke \& Lebeling 1894 (Księga pamiątkowa na jubileusz trzysta pięćdziesięciolecia Królewskiego Gimnazjum Mariackiego w Szczecinie 1544-1894), przedstawiono kopie widoków szkoły D.Ch. Meyera z 1799 roku, F.L. Kirchhoffa z 1804 roku, S.E. Hofmanna z 1832 roku oraz widok szkoły w 1884 roku, dzieło nieznanego autorstwa, być może samego E. Fobkego albo kopię kompozycji innego artysty ${ }^{42}$.

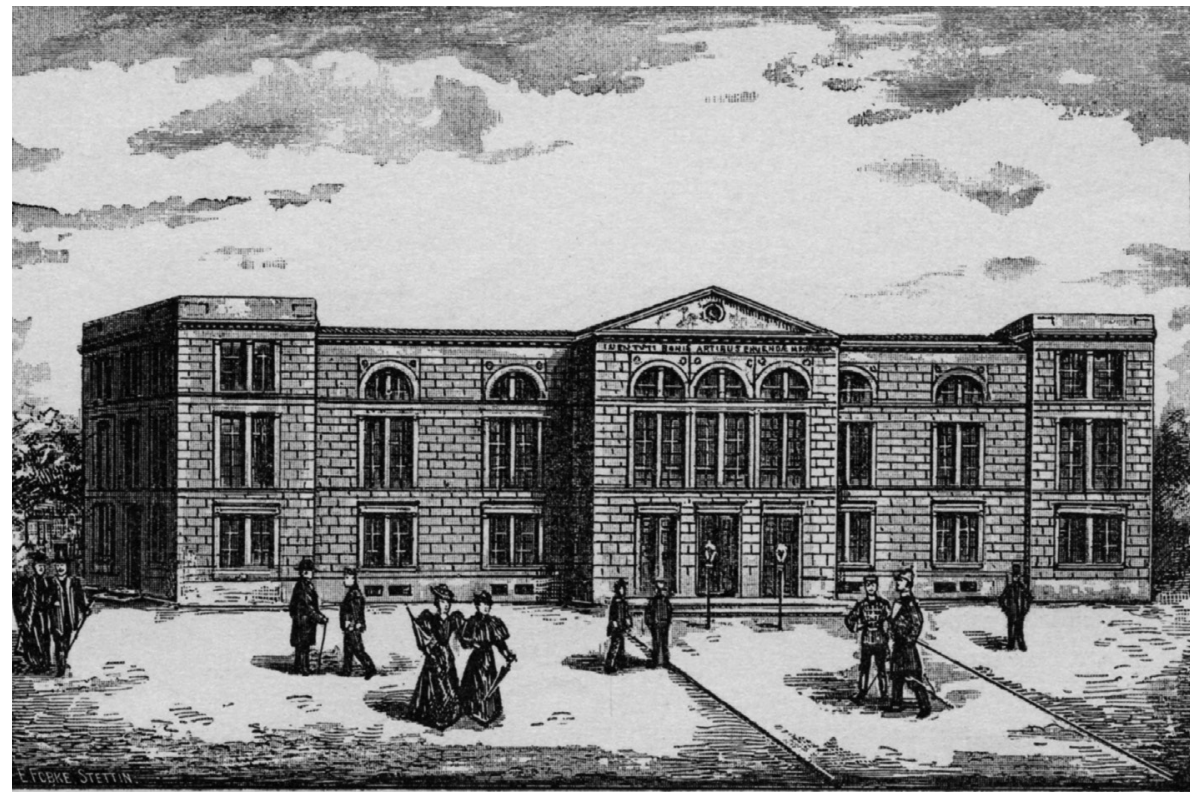

Rycina 13. E. Fobke, Gimnazjum Mariackie po rozbudowie w 1884, 1894, drzeworyt, papier, fragment frontyspisu w: Martin Wehrmann,

Festschrift des Marienstifts-Gymnasiums, Stettin 1894, Archiwum Państwowe w Szczecinie (fot. Ewa Gwiazdowska)

Ta ostatnia kompozycja jest jedynym znanym artystycznym przedstawieniem gimnazjum po rozbudowie XIX-wiecznego gmachu, przeprowadzonej w latach 1882-1884. Polegała ona na przedłużeniu gmachu z obu stron o jednoosiowe, ryzalitowe dobudówki zwieńczone pełnymi attykami, które otrzymały tę samą wysokość, co gmach główny. Natomiast różniły się od starego korpusu

${ }^{42}$ Papier, wym. karty 260 x 318 mm, wym. przedstawienia z 1884 roku 169 x 104 mm, Biblioteka Archiwum Państwowego w Szczecinie, sygn. 10883. 
zastosowaniem w górnej kondygnacji okien prostokątnych zamiast zamkniętych półkoliście i w rezultacie tego zabiegu osie okienne straciły optyczną jednolitość - stały się osiami podwójnymi. Jednocześnie rozbudowa nadała budowli charakter bardziej monumentalny.

W XX wieku gmach szkoły udokumentowano na zdjęciach, stosując znane XIX-wieczne ujęcia fasady od południowego zachodu bądź od południowego wschodu $^{43}$. Jedno $\mathrm{z}$ tych zdjęć ukazuje otoczenie gmachu od strony południowo-zachodniego naroża pl. Mariackiego około 1933/1934 roku, kiedy funkcjonował tu punkt akcji dobroczynnej, „Winterhilfe” (Pomoc zimowa). Świadczy o tym baner umocowany nad wejściem do budynku ${ }^{44}$.

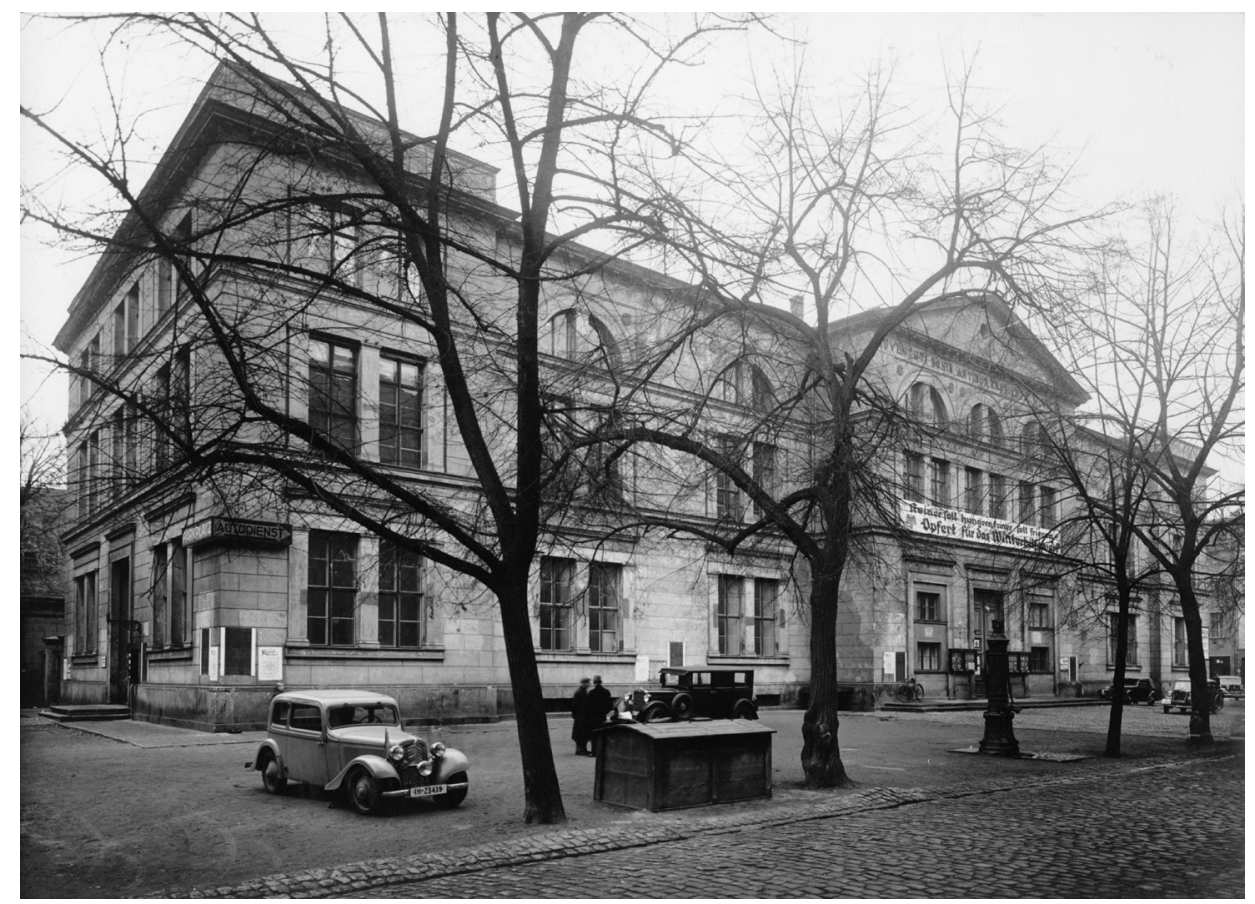

Rycina 14. Widok dawnej siedziby Gimnazjum Mariackiego około 1933/1934 roku jako punktu akcji „Pomoc zimowa”, fotografia, papier, Muzeum Narodowe w Szczecinie (fot. archiwalna)

${ }^{43}$ Pojedyncze zdjęcia obu zachowanych gmachów szkoły znajdują się w MNS: nr neg. MNS/ AFoto/:15574. Czasochłonna i kosztowna kwerenda zdjęć i kart pocztowych w polskich i niemieckich zasobach instytucjonalnych, a szczególnie prywatnych, mogłaby ewentualnie dostarczyć materiału do osobnej publikacji, ponieważ jednak istnieją budynki, w których funkcjonowała szkoła od 1832 roku, jej przeprowadzenie nie jest istotne.

${ }^{44}$ Fotografia archiwalna, MNS, nr neg. MNS/AFoto/15516. 
Ulrich Lewin (1890-1950) ${ }^{45}$, grafik podejmujący tematykę szczecińskiej architektury, uwiecznił w 1938 roku panoramę Domów Profesorskich w zimowej aurze na rysunku węglem ${ }^{46}$. Dzięki jego dokumentalnie potraktowanemu ujęciu od strony naroża ul. Mariackiej znany jest wygląd tych domów krótko przed drugą wojną światową.

Ostatnia zmiana siedziby Gimnazjum Fundacji Mariackiej, gmach wzniesiony według projektu Sternberga opartego na koncepcji Emila Bluncka przy Schlutowstrasse (obecnej ul. Henryka Pobożnego) w latach 1913-1915, również została odnotowana przez artystów. Jednym z nich był Wilhelm Bormes (1887-1958), zatrudniony w tej szkole jako nauczyciel rysunku, podobnie jak wiek wcześniej A.L. Most. Bormes wykonał malownicze rysunki siedziby szkoły wkrótce po jej otwarciu ${ }^{47}$. Ukazał placówkę zarówno od strony klasycystycznej fasady, jak i od strony podwórza otoczonego przez trzy skrzydła budowli, w tym ujęciu przypominającej okazały barokowy pałac.

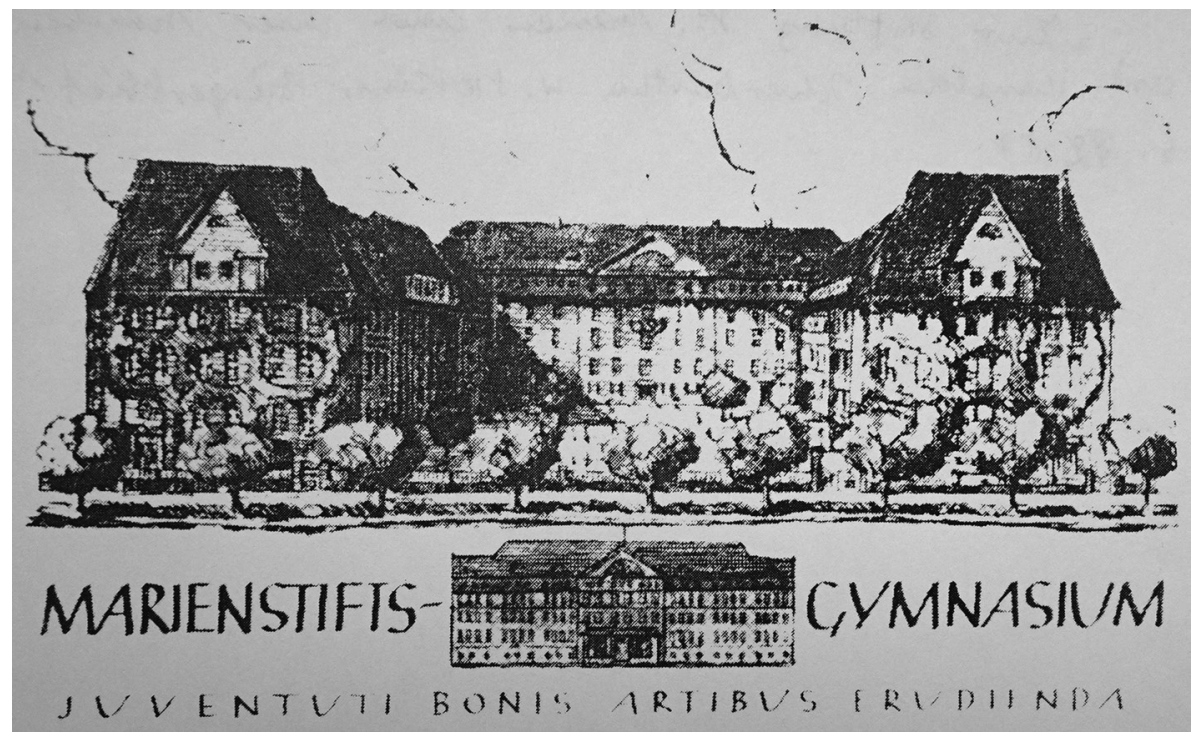

Rycina 15. Wilhelm Bormes, Widok fasady i elewacji tylnej siedziby Gimnazjum Mariackiego od 1916, niedatowany, pióro, tusz, papier, reprodukcja w: Harald Scherbarth, Zur Stiftung St. Marien und ihrer Schulen, Stettiner Bürgerbrief (1993): 85.

\footnotetext{
${ }^{45}$ Carmen Lewin-Stern, „Der Künstler Ulrich Lewin”, Pommern. Zeitschrift für Kultur und Geschichte 4 (2016): 37.

${ }^{46}$ Brak wymiarów, fotografia archiwalna, MNS, nr neg. MNS/AFoto/5146.

${ }^{47}$ Brak danych technicznych, reprodukcja w: Scherbarth, „Zur Stiftung”, 85.
} 
Najnowszy gmach gimnazjum znalazł się pośród obiektów szczecińskiej architektury udokumentowanych na fotografiach ${ }^{48}$. Dzięki temu wiadomo, że przed fasadą szkoły zasadzono szpaler drzew zgodnie z ówczesnym przekonaniem, że rośliny dodają budowlom elegancji. Drzewa nie tylko podkreślały estetykę elewacji, ale i niwelowały surowość ścian. Niestety, zastosowane przez fotografów ujęcia pozwalają jedynie porównać ogólny wygląd szkoły z jej dzisiejszą formą. Brak zdjęć zdobiących fasadę detali rzeźbiarskich wykonanych w nietrwałym trawertynie. Rzeźby bohaterów antycznych mitów: Penelopa, Odyseusz i Telemach po lewej stronie, a Orestes, Ifigenia i Thoas ${ }^{49}$ po prawej oraz dewiza przeniesiona z portalu szkoły przy pl. Mariackim: IUVENTUTI BONIS ARTIBUS ERUDIENDAE (Młodzieży, która ma się kształcić w dyscyplinach humanistycznych) umieszczone po obu stronach gzymsu portalu przypominają o kultywowanej w szkole tradycji idei neohumanistycznych ${ }^{50}$.

Opisane przykłady widoków i planów założenia najstarszej i najważniejszej szczecińskiej szkoły, funkcjonującej przy kościele Mariackim, a potem na jego miejscu, co podkreśla symbolikę szkoły, nie wyczerpują zagadnienia ikonografii tej placówki. Są to jednak przedstawienia najistotniejsze i szerzej znane, dlatego można je uznać za wybór reprezentatywny dla problemu ikonografii szkoły Mariackiej. Stanowią cenne źródło obrazowe nie tylko do obserwacji przekształceń architektonicznych i urbanistycznych założenia edukacyjnego wraz ze zmieniającymi się stylami i przekonaniami o stosowności danego stylu do zastosowania w gmachu szkolnym. Dowodzą, że od średniowiecza do początku XIX wieku kontynuowano tradycję, zgodnie z którą szkoła była nie tylko gmachem, w którym odbywało się kształcenie, ale całym kompleksem budynków obejmujących większość funkcji niezbędnych do egzystencji szkolnej zbiorowości, podobnie jak społeczności klasztornej. Obrazowe źródła świadczą o znaczeniu tej szkoły jako instytucji prestiżowej dla miasta i jego wizerunku, uznawanej za taką zarówno przez jego mieszkańców i władze, jak i władców państwa. Wszak po uniwersytecie w Greifswaldzie szkoła Mariacka stanowiła drugą najważniejszą placówkę naukową Pomorza. Traktowano ją jak wizytówkę Szczecina, czego dowodem jest

\footnotetext{
${ }^{48}$ Fotografie archiwalne: MNS, nr neg. MNS/AFoto/15956; Weishaupt, Deutschland, 45.

${ }^{49} \mathrm{Za}$ informację o tej ostatniej postaci udzieloną mi w trakcie konferencyjnej dyskusji dziękuję Pani dr Małgorzacie Cieśluk, hellenistce z Uniwersytetu Szczecińskiego.

${ }^{50}$ Por. Hermann Mantzke, „Zur Geschichte des Marienstifts-Gymnasiums”, Krause, Stettin auf weißem: 47; Na temat pochodzenia i znaczenia idei kształcenia młodzieży w oparciu o wzorce sztuk pięknych, literatury, historii i filozofii w duchu antyku greckiego por. Agnieszka Zabłocka-Kos, Zrozumieć miasto. Centrum Wroclawia na drodze ku nowoczesnemu city 1807-1858 (Wrocław: Wydawnictwo Via Nova, 2006), 167-168.
} 
zarówno zidentyfikowane słownie przedstawienie Pedagogium na widoku Fransa Hogenberga z 1590 roku, jak i wiele panoram Domów Profesorskich z wieków późniejszych. Owe domy po urbanistycznej przebudowie miasta w okresie baroku, z nieznaczących budynków stojących na obrzeżach miasta, wzdłuż średniowiecznego muru miejskiego, przekształcono w reprezentacyjną fasadę jednego z głównych placów miasta - Placu Parad.

Widoki i plany założenia Fundacji Mariackiej pojawiały się w dziejach w różnych kontekstach. W okresie nowożytnym plany szkoły były głównie elementem planów miasta, atlasowych czy katastralnych. Widoki stanowiły jeden z motywów przedstawień miasta, jego wnętrz urbanistycznych. Jako odrębny temat ilustrowały dzieła historyczne, na przykład jako frontyspis. Widok biblioteki był elementem cyklu kompozycji upamiętniających pożar kościoła Mariackiego. Zarówno z czasów nowożytnych, jak i z XIX wieku pochodzą przedstawienia inwentaryzacyjne i projektowe, które są dobrymi źródłami wiedzy o faktycznym i planowanym wyglądzie budowli szkolnych. W XIX i XX wieku widoki gimnazjum stały się samodzielnym tematem, rzadziej motywem, dzieł sztuki i rzemiosła artystycznego, jako przedstawienia pamiątkowe. Wykonywanie rzadkich XX-wiecznych fotografii związane było z dokumentowaniem zabudowy Szczecina. Niektóre z nich wykorzystane zostały jako ilustracje w książce z popularnego cyklu poświęconego zabudowie miast niemieckich ${ }^{51}$.

Źródła ikonograficzne świadczą o tym, że nowe siedziby szkoły należały do pomników architektury i najbardziej godnych uwagi budowli Szczecina. Uznane były za budowle reprezentacyjne, z których miasto było dumne, jak również za obiekty sentymentalne dla szczecinian, a godne upamiętnienia dla turystów. Widoki najnowsze, XX-wieczne, nie tylko mówią o rozwoju urbanistycznym miasta po zniesieniu statusu twierdzy i likwidacji fortyfikacji. Nowa lokalizacja szkoły - w okolicy obecnych Wałów Chrobrego - świadczy, że nadal miała ona status wyjątkowej placówki edukacyjnej. W dziejach ikonografii szkoły Mariackiej odbijają się dzieje samego miasta.

\section{Bibliografia}

Białecki, Tadeusz. Szczecin na starych widokach (XVI-XX wiek). Stettin auf Alten Abbildungen (16.-20. Jahrhundert). Szczecin: Archiwum Państwowe w Szczecinie, 1995.

\footnotetext{
${ }^{51}$ Por. przypis 16.
} 
Borysowska, Agnieszka. „Biblioteka szczecińskiego Gimnazjum Akademickiego w XVIII w.”. W: Od Pedagogium Książęcego do Gimnazjum Mariackiego. Z dziejów szkolnictwa pótwyższego w Szczecinie do początków XIX w., red. A. Borysowska, 145-158. Szczecin: Książnica Pomorska, 2018.

Braun, Georg, Frans Hogenberg. Civitates orbis terrarium. T. 1. Liber quartus urbium praecipuarum ...totius mundi. Coloniae Agrippinae: Georg Braun, 1590.

Fredrich, Carl. „Die ehemalige Marienkirche zu Stettin und ihr Besitz. II”. Baltische Studien. Neue Folge 23 (1920): 3-60.

Gwiazdowska, Ewa. Widoki Szczecina. Źródła ikonograficzne do dziejów miasta od XVI wieku do 1945 roku. Ansichten von Stettin. Ikonographische Quellen zur Stadtgeschichte vom 16. Jahrhundert bis zum Jahr 1945. Szczecin: Muzeum Narodowe w Szczecinie, 2001.

Gwiazdowska, Ewa, Rafał Makała, red. August Ludwig Most. Pomorski artysta epoki biedermeieru. Der Pommersche Künstler der Biedermeierzeit. Szczecin: Muzeum Narodowe w Szczecinie, 2007.

Holtze, Otto, oprac. Das Stadtbild Stettins vom 16. Jahrhundert bis zur Gegenwart in Gemälden, Zeichnungen und Bilddrucken der Zeit. Ausstellung veranstaltet vom... Stettin: Museum der Stadt Stettin vom 18. Oktober bis 15. November 1936. Stettin: Museum der Stadt Stettin, 1936.

Kozińska, Bogdana. „«Młodzieży dla wychowania w dobrych obyczajach». Opis nowego budynku szczecińskiego Gimnazjum Mariackiego sprzed 180 lat”. Szczeciner. Magazyn miłośników Szczecina 2 (2012): 165-171.

Kozińska, Bogdana. Rozwój przestrzenny Szczecina od początku XIX wieku do II wojny światowej. Szczecin: Muzeum Narodowe w Szczecinie, 2015.

Krause, Hans Herbert. „Stettin auf Weißem Gold. Veduten auf Porzellan des 18. und 19. Jahrhunderts". Stettiner Heft 20 (2017).

Lewin-Stern, Carmen. „Der Künstler Ulrich Lewin”. Pommern. Zeitschrift für Kultur und Geschichte 4 (2016): 37.

Makała, Rafał. „Gimnazjum Mariackie”. W: Maciej Słomiński, Rafał Makała, Małgorzata Paszkowska. Szczecin barokowy. Architektura lat 1630-1780, 113-122. Szczecin: Stowarzyszenie Historyków Sztuki Oddział w Szczecinie, 2000.

Scherbarth, Harald. „Zur Stiftung St. Marien und ihrer Schulen”. Stettiner Bürgerbrief (1993): 72-87.

Wehrmann, Martin. Festschrift zum freihundertfünfzigjährigen Jubiläum des Königlichen Marienstiftsgymnasiums in Stettin 1544-1894. Stettin: Herrcke \& Lebeling, 1894.

Weishaupt, Karl, oprac. Deutschland Städtebau. Stettin. Berlin-Halensee: Deutscher Architektur- und Industrie Verlag, 1925.

Zabłocka-Kos, Agnieszka. Zrozumieć miasto. Centrum Wrocławia na drodze ku nowoczesnemu city 1807-1858. Wrocław: Wydawnictwo Via Nova, 2006. 


\begin{abstract}
Abstrakt
Gimnazjum Fundacji Mariackiej już od początku istnienia, jako szkoła katedralna, aż po XX wiek uważane było za najważniejszą szkołę Szczecina. Znajdowało się pod protektoratem władców Pomorza i przez długi czas miało status szkoły akademickiej. Odzwierciedliło się to w obrazowych dziejach szkoły. Jej ikonografia sięga ostatniego ćwierćwiecza XVI wieku i rozwija się po wiek XX. Tworzą ją głównie dzieła graficzne, są to, często zachowane tylko w postaci archiwalnych fotografii, plany, rysunki inwentaryzacyjne, projektowe, artystyczne oraz ilustracyjne, grafiki dokumentacyjne i okolicznościowe, a także zdjęcia. Warto zauważyć, że w XIX wieku powstało także wiele pamiątkowych wyrobów ceramicznych. Źródła te mają różny stopień dokładności. Materiały z okresu nowożytnego (XVI-XVIII wiek) poza inwentaryzacyjnymi są mniej wiarygodne. Wierne przedstawienia szkoły powstawały w XIX i XX wieku. Całokształt źródeł dostarcza jednak wiedzy o formie szkoły i jej zmianach w ciągu wieków, uzupełnia informacje ze źródeł pisanych i pozwala na wielostronną orientację w tym zagadnieniu.
\end{abstract}

\title{
A JeWel of the country: From Pedagogium TO THE MARIAN GYMNASIUM - AN ICONOGRAPHY
}

\begin{abstract}
The Gymnasium of the Marian Foundation since the beginning of its existence as a cathedral school until the $20^{\text {th }}$ century was considered the most significant school in Szczecin. It operated under the patronage of the rulers of Pomerania and for a long time had a status of a higher education school, which has been mirrored in the pictorial history of the school. Its iconography dates back to the last quarter of the $16^{\text {th }}$ century and was developing until $20^{\text {th }}$ century. It consists mainly of the works of graphic art, often preserved as the archival photographs of the plans, survey drawings, project drawings, artistic and illustrative drawings, documentation and occasional graphics, as well as the photographs themselves. It is worth noting that in the $19^{\text {th }}$ century many commemorative ceramic objects were also made. These sources differ in the level of accuracy. Materials from the modern period $\left(16^{\text {th }}-18^{\text {th }}\right.$ centuries $)$, besides the survey drawings, are less reliable. The accurate representations of the school were made in the $19^{\text {th }}$ and $20^{\text {th }}$ centuries. However, the sources as a whole provide knowledge of the school's form and its changes during centuries, complete the information from the written sources, and ensure a wide-ranging understanding of the topic.
\end{abstract}

